\title{
Consequences of Quarantine During the COVID-19 Pandemic on Food Intake and Body Weight: A Systematic Review
}

Paula Moreira Penna ( $\sim$ paula.penna@ufv.br)

Universidade Federal de Viçosa, UFV

Nathallia Maria Cotta e Oliveira

Universidade Federal de Viçosa, UFV

Luiza Carla Vidigal Castro

Universidade Federal de Viçosa, UFV

Helen Hermana Miranda Hermsdorff

Universidade Federal de Viçosa, UFV

\section{Research Article}

Keywords: COVID-19, SARS-CoV-2, quarantine, food intake, eating habits, body weight changes, weight gain

Posted Date: October 28th, 2021

DOl: https://doi.org/10.21203/rs.3.rs-953160/v1

License: (9) This work is licensed under a Creative Commons Attribution 4.0 International License. Read Full License 
Consequences of Quarantine During the COVID-19 Pandemic on Food Intake and Body Weight: A Systematic Review

Paula M Penna ${ }^{1 *}$, Nathallia M C e Oliveira ${ }^{1 *}$, Luiza C V Castro ${ }^{1,2}$, and Helen H M Hermsdorff $^{1,2 *}$

${ }^{1}$ Department of Nutrition and Health, Universidade Federal de Viçosa, UFV, Viçosa, Minas Gerais, Brazil; paulapenna_@hotmail.com; nathallia.oliveira@ufv.br; luiza.castro@ufv.br; helen.hermana@ufv.br

2 Institute of Public Policies and Sustainable Development, UFV, Viçosa, Minas Gerais, Brazil; luiza.castro@ufv.br; helenhermana@ufv.br

* Correspondence: Helen Hermana Miranda Hermsdorff, Department of Nutrition and Health, Universidade Federal de Viçosa, Av. PH Rolfs s/n, Viçosa, Minas Gerais 36570-900, Brasil. E-mail: helenhermana@ufv.br. Tel.: +55 31 3612-5195 


\begin{abstract}
Background: Due to the coronavirus disease (COVID-19) pandemic, some authorities have implemented measures to control the spread of the severe acute respiratory syndrome coronavirus 2 (SARS-CoV-2), such as quarantine. The aim of this systematic review was to summarize the results of the studies that investigated changes in eating habits, food intake, and body weight during the COVID-19 quarantine.
\end{abstract}

Methods: This review followed the recommendations of the PRISMA protocol and has registration in the PROSPERO under number CRD42020212491. Searches used databases PubMed, Medline, Scielo, and Lilacs. Two authors conducted the selection process blindly and independently using the Rayyan software (QCRI). Of 5,248 papers, we included 28 studies.

Results: Most of the included studies in this review presented data on changes in food intake $(n=22)$. These changes were especially towards the adoption of unhealthy eating habits such as an increase in the consumption of snacks and sweets; and a decrease in the intake of vegetables, fruits, fish, and dairy products $(n=21)$. Concerning body weight, the main change was towards weight gain (1.5 to $4.5 \mathrm{~kg}$ ), which was positively associated with age (elderly); socioeconomic level (average socioeconomic level); increase of the intake of snacks, sweets, fried foods, and fast foods; and low consumption of vegetables. Besides, weight gain was inversely associated with physical activity and positively associated with sedentary time $(n=14)$.

Conclusion: In this sense, the summarized evidence points to a change in eating habits, food intake, and body weight, as well as a relevant association between unhealthy eating choices and weight gain during quarantine. The COVID-19 quarantine caused an interruption in the routine of daily life, which generated an impact on mental health, 
eating habits, and physical activity. This review showed that during the quarantine some individuals changed their eating habits, mainly towards the adoption of unhealthy habits and gained weight.

Keywords: COVID-19, SARS-CoV-2, quarantine, food intake, eating habits, body weight changes, weight gain 


\section{Introduction}

In December 2019, an unknown disease first identified in Wuhan, Hubei, China, named as 2019-nCoV and later renamed COVID-19 by the World Health Organization (WHO), warned the medical and scientific communities $(1,2)$. This disease quickly spread in several countries and on 11 March 2020 was declared as a pandemic by the WHO (3). The statistical data of the COVID-19 of July 2021 show that more than 184 million people already were infected and more than 3,9 million died worldwide (4). Its symptoms range from those most common such as cough and fever to those more severe such as shortness of breath, and other uncommon ones, such as loss of taste and smell (5).

The COVID-19 is caused by severe acute respiratory syndrome coronavirus 2 (SARS-CoV-2) that spreads from person to person through droplets generated by coughing, sneezing, and talking. Containment strategies in the face of the growing number of cases revolve around social distancing, quarantine, and public places' closure. Despite the benefits provided by such strategies in combating the spread of the virus, these measures can favor the occurrence of adverse health effects, especially because they can cause an interruption in the practice of physical activity, an increase of the risk of anxiety and boredom due to social isolation, as well as can negatively affect food choices. $(3,6-9)$.

Quarantine is describing as a measure to isolate those who have contact with an infectious disease and, subsequently, to prevent its spread. There is also the reverse quarantine, a measure that isolates those belonging to the greatest risk of contracting the disease. These measures differ from isolation, a measure of distance from those affected by the infectious disease during the disease incubation period (10). 
The lifestyle has undergone many changes in the face of COVID-19 quarantine, with emphasis on the increase of food consumption, decreased physical activity, increased sedentary time, excessive screen time, and poor sleep quality (11-13). These changes can have been generated by the psychological and restrictive impact caused by this measure. The quarantine can have a direct impact on mental health, especially on the development of anxiety, distress, a feeling of loss of control, loneliness, depressive symptoms, and post-traumatic stress disorder (14). All these feelings contribute to the worsening of the quality of food, with an increased risk of developing "emotional eating" and weight gain (15).

Although the WHO published that good nutrition is crucial for health, particularly when the immune system might need to fight back (16), changes in food intake and eating habits during COVID-19 quarantine may not be in line with the recommendation. Some studies have demonstrated that COVID-19 quarantine contributed to increased intake of energy, sodium, and fat; and decreased fruits and vegetables consumption $(3,6,17)$. These negative changes in dietary patterns may result in weight gain, activation of the innate immune system and inhibition of the adaptive, increase in the production of inflammatory mediators, and other factors that can influence COVID-19 $(17,18)$. On the other hand, healthy dietary patterns including a high intake of fruits and vegetables and low consumption of sugar and saturated fats can prevent chronic diseases and improve related-chronic low-grade inflammation (19-21).

In addition to changes in food intake, some studies also have shown that during COVID-19 quarantine there was a change in body weight, especially towards to increase of the self-reported weight $(22,23)$. Excessive weight gain can lead to obesity that is increased worldwide and characterized by an increase of body fat (24) and low- 
grade inflammation, which is a recognized link between obesity and other chronic diseases $(25,26)$.

Emerging evidence shows that obesity can be a risk factor for poor outcomes by COVID-19 and still a predictor of mortality (27-29). This occurrence can potentiate the aggravating factors of COVID-19 due to the increase of pro-inflammatory adipokines that contribute to establishing inflammation and oxidative stress. Moreover, obesity seems to impact lung function and immune responses $(30,31)$. Besides, obesity is associated with some comorbidities, such as hypertension and diabetes, which also have been considered risk factors for complications of the COVID-19 (32). However, it's important to emphasize that there are other factors important that influence the mortality by COVID-19, such as age, e.g. elderly individuals are more likely the complications and mortality when compared with younger individuals (33).

In this sense, the aim of the present systematic review was to compile the studies that investigated changes in eating habits, food intake, and body weight during the COVID-19 quarantine. We summarize the main changes in eating habits, food intake, and body weight resulting from quarantine, as well as the factors that impacted these changes. In addition, we investigate whether changes in the food intake were associated with the change in weight body.

\section{Methods}

This is a systematic review guided by the following question: What are the consequences of quarantine during the COVID-19 pandemic on eating habits and body weight? This review follows the recommendations of the Preferred Reporting Items for Systematic Reviews and Meta-Analyzes (PRISMA) and has a registration in International Prospective Register of Systematic Reviews (PROSPERO) under number CRD42020212491. 
Searches for articles were in the databases: National Library of Medicine, Bethesda, MD (PubMed), Scientific Electronic Library Online (SciELO), LatinAmerican and Caribbean System on Health Sciences Information (LILACS), and Medical Literature Analysis and Retrieval System Online (Medline), without delimiting the search period and conducted between October 2020 and March 2021. We used the descriptors "COVID-19", "Food Intake", "Nutrition" and "Eating Behavior" indexed in the Medical Subject Headings (MeSH), their related terms, and their combination by the boolean operators AND and OR in different ways in these databases (Figure 1).

Two authors (PMP and NMCO) independently made the paper selection using the Rayyan QCRI website, the Systematic Reviews web app. This selection is according to a protocol previously established by the authors, where authors selected the articles by reading the titles and abstracts and later by reading them in full. The inclusion criteria were original articles, published in English, Portuguese or Spanish, conducted with adolescents, adults, and elderly individuals with or without underlying diseases, and in whose paper the main objective was to assess the influence of quarantine on changing food intake and/or body weight. The exclusion criteria were reviews, studies conducted with children, original studies conducted with animals, and those that did not obtain relevant information to clarify the guiding question. These criteria were adopted so that the objectives previously established were achieved (Table 1).

The following data were extracted and compiled independently by 2 authors (PMP and NMCO): first author, year of publication, country, study design, sample, sample size, objectives, and outcomes concerning changes in food intake and body weight. The data are in alphabetical order followed by the name of the first author of the study. 
Two authors (PMP and NMCO) also evaluated the article's methodological quality. The cross-sectional studies were assessed using a checklist with questions focused on cross-sectional studies, Checklist for analytical cross-sectional studies, Joana Briggs Institute (34). Then, the same authors classified articles as low $(<50 \%)$, moderate (50-70\%), and high quality (> 70\%), according to the degree of contemplation of criteria related to the clarity of the inclusion of individuals in the study, description of the scenario, the measurement made validly and reliably. The observational and longitudinal studies were assessed by the tool for assessing Risk of bias in nonrandomized studies of interventions (ROBINS-I). The authors classified the articles as moderate or low risk, according to the domains specified in ROBINS-I, which include (1) bias due to confounding, (2) bias in the selection of participants into the study, (3) bias in classification of interventions, (4) bias due to deviations from intended interventions (5) bias due to missing data, (6) bias in the measurement of outcomes, (7) bias in the selection of the reported result and (8) overall risk of bias (35).

\section{Results}

\section{Selected Studies}

The search identified 5,248 articles. Of these, 28 articles composed this review. The years of publication of the studies were 2020 and 2021. Most articles have a crosssectional design $(n=25)$, longitudinal $(n=2)$ and retrospective observational study $(n=$ 1). Sample sizes vary, with a population of 72 to 41.923 individuals, including adolescents, adults and the elderly. Most country studies were from Europe, such as Spain $(n=7)(2,17,36-40)$, Italy $(n=5)(41-45)$, Poland $(n=3)(23,46,47)$, Germany $(n$ = 1) (48) and the Netherlands $(n=1)(49)$ followed by China $(n=2)(50,51)$, United States ( $\mathrm{n}=1$ ) (52), Chile $(\mathrm{n}=1)$ (53), United Arab Emirates $(\mathrm{n}=1)(54)$, Zimbabwe (n 
= 1) (55), Lithuania $(\mathrm{n}=1)(22)$, United Kingdom $(\mathrm{n}=1)(56)$, Brazil $(\mathrm{n}=1)(57)$. Other studies included countries in Europe, Africa, Asia and America $(\mathrm{n}=1)(58)$, and which included individuals from Italy, Spain, Chile, Colombia and Brazil $(n=1)(18)$ (Table 2 and 3).

\section{Changes in Food Intake and Eating Behavior}

Most of the included studies presented data on changes in food intake $(n=22)$ $(2,17,18,22,36,37,39,40,42,44,46-51,53-58)$. In this sense, some studies have found increased food intake $(n=2)(36,42)$ or the number of meals $(n=5)(36,46,47,54,58)$. The adoption of healthy eating habits reported by some studies $(n=11)$ it concerns the increased consumption of fruits, vegetables, fish, dairy products, grains, water, and decreased consumption of fast food, sweets, sweet drinks, and ready-made foods. The consumption of fruits and vegetables increased by up to $37 \%$ and $43 \%$, respectively, fish and dairy products by $30 \%$, grain by $37 \%$, and water by $3.7 \%$, while reduction in fast food consumption went from $44.6 \%$ to $64 \%$, ready-to-eat foods in $2 \%$, sweet foods in $50 \%$ and sweet drinks in $30 \%$ during quarantine $(2,17,18,22,36,39,42,44,46-50,53$ 55) (Table 2).

Other studies $(n=21)$ reported unhealthy eating habits related to an increase in snacks and sweets, and a decrease in vegetables, fruits, fish, dairy products, vegetables, and soy products. The consumption of snacks and sweets increased $51.8 \%, 50 \%$, respectively. The consumption of vegetables and fruits decreased $60 \%$, fish to $57.2 \%$, dairy products $30 \%$ and vegetables $70 \%(2,17,18,22,36,37,40,42,44,46-51,53-58)$.

Some studies have found changes in alcohol intake $(n=7)$, with a decrease during quarantine by up to $57.3 \%$, and an increased by up to $18.3 \%$ $(17,22,36,39,46,55,58)$. 
Some articles evaluated factors that impacted food intake. The reported factors were boredom/solitude by $36 \%$ and anxiety/depression by $34.7 \%$ of those who participated in one study (44); eating in response to the sight and smell of food by $65 \%$, eating when stressed by $52 \%$, anxious by $41 \%$, and bored by $73 \%$ of the respondents in another study (52); and the increased mental stress in a third study (48). The study of Zachary et al. (52) found that a large increase in eating in response to stress is one of the risk factors for weight gain, ranging from 5 to 10 pounds and the study of Huber et al. (48) found that mental stress was associated with increased of the amount of food during quarantine.

\section{Changes in Body Weight}

In this review, fourteen studies reported changes in body weight $(22,23,36-$ 38,40,41,43-46,52-54). Regarding body weight, fourteen reported weight gain $(22,23,36-38,40,41,43-46,52-54)$, four weight loss $(23,36,52,53)$, and five weight maintenance $(22,40,52-54)$. Moderate studies increased body weight by up to $52.7 \%$, with an average increase of 0.4 to $4.5 \mathrm{~kg}(38,52)$. This weight gain was positively associated with age (elderly) (54), socioeconomic level (average socioeconomic level) (53), consumption of snacks $(22,37)$, sweets (44), fried foods and fast food (53) and low consumption of vegetables (53).

Weight gain also had an inverse association with physical activity and a positive association with sedentary time $(22,53)$ (Table 3$)$. Weight loss was reported by a smaller portion of $4 \%$ to $31.1 \%$ and with an average loss greater than $4.5 \mathrm{~kg}$, with the reported weight maintenance being up to $68.5 \%$ of respondents $(36,52,53)$.

\section{Quality Assessment of Articles}

The articles included obtained a positive evaluation in general, and all obtained a positive evaluation, none of the criteria related to the analysis performed $(n=25)$, 
followed by the one referring to the description of the study scenario $(\mathrm{n}=25)$, validation and confidence of the evaluation method of the study $(n=25)$. Study exposure $(n=25)$, definition of parameters for measuring variables $(n=24)$, definition of inclusion criteria $(n=22)$. The criteria for identifying confounding factors obtained intermediate adherence $(\mathrm{n}=15)$. Standardization and objectivity criteria in determining conditions $(n=13)$ and strategy for dealing with confounding factors have been poorly met $(n=10)$.

The three studies evaluated by ROBINS-I tool showed in general a low risk, according to the eight domains. The articles were judged within each domain and presented a moderate risk of bias due to confounding $(n=3)$, low risk of bias in the selection of participants into the study $(n=2)$, moderate risk of bias in the selection of participants into the study $(n=1)$, low risk of bias in classification of interventions $(n=$ 3), low risk of bias due to deviations from intended interventions $(n=3)$, low risk of bias due to missing data $(n=3)$, moderate risk of bias in the measurement of outcomes $(n=3)$, low risk of bias in the selection of the reported result $(n=3)$, and low risk of overall bias $(n=3)$.

\section{Discussion}

To our knowledge, this is the first systematic review that compiled evidence about the influence of COVID-19 quarantine on changes in food intake, body weight, and its inter-relationship. In this sense, eating habits were healthier or unhealthier than those observed before quarantine, which was related to body weight changes (Figure 2).

The adoption of healthy eating habits found in this review may be an essential strategy for strengthening the immune system, in order to improve response to infections (59). The Food and Agriculture Organization of the United Nations (FAO) recommends that during the COVID-19 pandemic, people adopt a healthy diet to 
support the immune system functions. In this sense, this agency recommendations the consumption of a diet rich in fruits, vegetables, whole grains, nuts, and healthy fats such as oils rich in unsaturated fatty acids; a limited intake of foods with high amounts of fats, sugar, and salt; a regular water consumption; and limited alcohol consumption (60).

The immunological system is active full-time, thereby, when pathogens agents, such as the SARS-CoV-2, infect a human cell, innate and adaptive immune response, as well events mediated by the complement system may be a trigger to control the infection and eliminate the pathogen. In this perspective, the induction of an adequate host immune response can protect the organism against more severe complications of diseases such as COVID-19. On the other hand, if the generated immune response is insufficient, may occur, for example, increased viral replication, resulting in tissue damage (61). Several nutrients are involved with the adequate immune response, thus, the adoption of a healthy diet is important for the adequate supply of these nutrients (62).

Considering this context of immunity, the increased consumption of fruits, vegetables, fish, and dairy products found in this review was beneficial. For example, fruits and vegetables contain micronutrients that act on the adaptive immune system, production of antibodies, anti-inflammatory regulation through antimicrobial activity, among other aspects of combating viral infections $(63,64)$. Interestingly, Hermsdorff et al. (25) showed that higher consumption of fruits and vegetables was associated with a lower mRNA expression in peripheral blood mononuclear cells (PMBC) of certain proinflammatory markers, including the transcription of nuclear factor- $\kappa \mathrm{B}(\mathrm{NF}-\kappa \mathrm{B})$. In addition to essential vitamins and minerals, fruits and vegetables are also important 
sources of antioxidants, which allow the maintenance of immune cell function, through protection against oxidative stress $(19,65-67)$.

In turn, fish contains unsaturated fatty acids such as eicosapentaenoic acid (EPA) and docosahexaenoic acid (DHA) that prevent lung damage, mainly through antiinflammatory pathways (63). The anti-inflammatory activity of these essential fatty acids can reduce the eicosanoids formation, which has pro-inflammatory characteristics, derived from arachidonic acid metabolism (68). On the other hand, dairy products could influence the immune system response to COVID-19 through vitamin D, which reduces the risk of viral infections through physical barriers and natural immunity and induction of the innate immune system $(64,69)$.

Therefore, the evidence with animal models and human studies indicates that specific nutrients participate in the differentiation and maturation of immune cells; guarantees the integrity of physical, chemical, and biological resistant barriers; increases the activity of natural killer cells and $\mathrm{T}$ lymphocytes; improves the production of antibodies and favors the phagocytosis process (62). In this sense, the consumption of a diversified and varied diet, as recommended by the healthy eating guidelines, is essential to support the immune system's functioning. Furthermore, considering the benefits of these foods, especially for the immune system, governments must reinforce the food guides and food and nutrition policies to guarantee healthier food choices in a pandemic situation such as COVID-19.

This importance of healthy food for the immune system can be recognized in the study of Zhao et al. (51) that observed a lower dietary diversity among people who lived in areas with a high number of confirmed cases of COVID-19. However, it is important to mention that no food or single nutrients are capable of preventing infection by COVID-19 (70). 
This review also observed unhealthy eating habits such as increased consumption of sweets, snacks, fried foods, and elevated frequency of ultra-processed foods during COVID-19 quarantine. These foods can favor the occurrence of chronic diseases such as obesity, which has been associated with complications of COVID-19 (71). The consumption of snacks favors an increase in the intake of sugar, salt, saturated fats, and substances for the exclusive use of industries, which are the main factors that contribute to the prevalence of obesity and type 2 diabetes $(72,73)$. The high intake of sweets and fried foods have also been associated with an increased risk of insulin resistance and type 2 diabetes (74). Besides, fried foods have shown a positive association with general and central obesity among people with high-energy intake from these foods (75). Concerning ultra-processed foods consumption, a recent systematic review and meta-analysis of 14 studies, 13 cross-sectional studies, and one cohort study reported a significant association of ultra-processed foods consumption with overweight and obesity (76). Meneguelli et al. (77) in their systematic review also demonstrated a positive association between ultra-processed foods intake and excess body weight, hypertension, dyslipidemia, and components of the metabolic syndrome.

In relation to alcohol consumption, some studies reported a decrease in the intake of alcoholic beverages $(17,22,39,55,58)$, while others showed an increased $(22,36,46)$. In the COVID-19 pandemic, the excess consumption of alcohol, 20-40 and 30-60g / day for women and men respectively, could increase the risk of infections, promotes apoptosis of $\mathrm{T}$ cells, increases symptoms of bronchitis, in addition to being a risk factor for pneumonia $(78,79)$.

In this review, we observe that emotional factors impacted the food choices and eating behavior during COVID-19 quarantine. Being bored contributed to eating unhealthier and for increased food intake, anxiety/depression influenced the eating 
habits, and the increased mental stress led to changes in food amount $(44,48,49,52)$. Quarantine is associated with interruption of the routine, which could result in boredom. Besides, continuously hearing or reading about the COVID-19 pandemic can lead to stress. Boredom has been associated with high consumption of protein, fats, carbohydrates, and energy, while stress can contribute to the greater desire for specific foods, known as "food craving" (1). Ruiz-Roso et al. (2) evaluated this desire for food in your study and showed that the increased consumption of snacks, vegetables, and dairy products significantly related to food cravings among the study population during the lockdown.

Regarding changes in body weight during COVID-19 quarantine, most studies revealed an increase in self-reported body weight and a greater perception of weight gain. This weight gain observed during the quarantine was associated with mood changes; psychological stress; increased consumption of sweets, sugary beverages, alcohol, and homemade pastries; consumption of fried foods and junk food $\geq 3$ times / week; increased snacking; sedentary time $\geq 6 \mathrm{~h} /$ day; decreased physical activity; and eat more than usual $(22,37,43,44,53,54)$. In this sense, the adoption of unhealthy eating habits, emotional changes, as well negative lifestyle during COVID-19 quarantine can have contributed to the weight gain in this review's analyzed studies.

The weight gain when excessive can lead to the development of obesity. Some studies have been associated obesity with complications and a worse prognosis of COVID-19 (71,80). A study conducted with 297 patients diagnosed with COVID-19 showed that overweight and obesity were independent risk factors of severe COVID-19 (81). Another study with 770 adult patients with COVID-19 demonstrated that obesity was associated with a significantly higher rate of intensive care unit (ICU) admission or death (27). In addition, a prospective cohort study including 5,795 adults and elderly 
hospitalized with COVID-19 found that mortality was significantly major in higher body mass index (BMI) (82). Studies have also been associating diabetes with the severity of SARS-CoV-2 infection and mortality by COVID-19 $(83,84)$.

Obesity contributes to establishing a low-grade chronic inflammation. The exacerbated release of cytokines such as interleukin- 8 and tumor necrosis factor can aggravate lung parenchyma injury. Moreover, this situation influences the development of several disorders such as insulin resistance and oxidative stress, which also lead to a greater propensity to infections, therefore, it has direct impacts on the worsening of the disease in question $(32,81,85)$.

Finally, in this review was observed that individuals with overweight and obesity were more likely to show negative changes in food intake and weight body during quarantine when compared to individuals with normal weight. Thus, high BMI was correlated with a greater desire for food, eat unhealthier, eat more than usual, lower diet quality, and weight gain $(2,22,49,56)$. In addition, individuals with depression were $49 \%$ more likely to elevated frequency of ultra-processed foods consumption incidence when compared with individuals without depression (57). Those findings show that individuals with overweight, obesity, and depression during adverse situations, such as quarantine can need more support and encouragement to maintain or adopt healthy habits. Moreover, it was noticed that studies carried out at the beginning of the quarantine period already pointed to a significant change in food intake and body weight. Thereby, it is suggested that quarantine was able to quickly promote changes in the behavior of the individuals in general $(2,18,44,58)$.

This review has limitations. The selected papers are mostly cross-sectional studies, thus, the outcomes cannot reflect the cause-effect between quarantine and changes in eating habits and body weight. Most of the studies included in this review 
were online surveys, consequently, participated of the studies individuals who had access to the internet, therefore, the total sample of this review may not reflect the population in general. The data on food intake and body weight were self-reported, however, in our experience, self-reported data showed good reliability (86). The studies included in this review were heterogeneous in terms of methods of assessment of the food consumption, as well as about the study population, that presented demographic characteristics and medical conditions different.

From an epidemiological perspective, the data found in this review are of great importance, since allowed us to observe that quarantine was capable of promoting negative changes in food intake and body weight in different populations. These changes can affect the metabolic control of several chronic diseases and create an overload even bigger for the public health system. Although events that require authorities to adopt quarantine as a restrictive measure are rare, these events can be unexpected and have a variable duration. In this sense, the knowledge of these changes becomes important for authorities to direct public health policies in quarantine situations. Concerning COVID-19, future studies should be conducted to assess the long-term effects of quarantine on food intake, eating habits, and body weight.

\section{Conclusions}

The evidence found points to a change in eating habits and body weight during quarantine, mainly towards the adoption of unhealthy habits and weight gain. Some countries may still need to adopt quarantine as a control measure of the COVID-19, in these cases, public policies that encourage healthy lifestyle habits are necessary to prevent the population from changing above all their eating habits and body weight. The adoption of healthy eating habits and the maintenance of weight can be important allies of the vaccine and other treatments of the COVID-19. 


\section{Acknowledgments}

We would like to thank the Research Support Foundation of the State of Minas Gerais, for the postgraduate scholarship conceded to Paula M Penna. CAPES for the postgraduate scholarship conceded to Nathallia M C e Oliveira. Network against to obesity at the state of Minas Gerais, Brazil - RENOB-MG project and CAPES for support.

Authors' contributions: PMP, NMCO, and HHMH: conception; PMP and NMCO: literature search, selection, and extraction; PMP, NMCO, LCVC, and HHMH: authors involved in data analysis and writing the paper; and all authors: read and approved the final version of this manuscript.

\section{Funding}

This work is supported by the Network for Combating Obesity in the State of Minas Gerais, Brazil - RENOB-MG project (Bolsa CNPq / MS / SAS / DAB / CGAN n ${ }^{\circ}$ 421098 / 2018-0), Foundation for Research Support of the State of Minas Gerais with the granting of the master's scholarship from PMP and CAPES Foundation (code 001), with the grant of the master's scholarship from NMCO. HHMH Hermsdorff is a CNPq Research Productivity Fellow.

\section{Availability of data and materials}

Data sharing does not apply to this article as no datasets were generated or analyzed during the current study.

\section{Declarations}

Ehical approval and consent to participate

Not applicable

\section{Consent for publication}

Not applicable

Competing interests

PMP, NMCO, LCVC, and HHMH, no conflicts of interest. 


\section{References}

1. Muscogiuri G, Barrea L, Savastano S, Colao, A. Nutritional recommendations for CoVID-19 quarantine. Eur J Clin Nutr 2020;74:850-851, https://doi.org/10.1038/s41430-020-0635-2.

2. Ruiz-Roso MB, Knott-Torcal C, Matilla-Escalante DC, Garcimartín A, SampedroNuñez MA, Dávalos A, Marazuela M. COVID-19 lockdown and changes of the dietary pattern and physical activity habits in a cohort of patients with type 2 diabetes mellitus. Nutrients 2020;12(8):2327, https://doi.org/10.3390/nu12082327.

3. Gallo LA, Gallo TF, Young SL, Moritz KM, Akison LK. The impact of isolation measures due to covid-19 on energy intake and physical activity levels in Australian university students. Nutrients 2020;12(6):1865, https://doi.org/10.3390/nu12061865.

4. WHO. Information about COVID-19. World Health Organization, 2021. Available from: https://www.who.int/emergencies/diseases/novel-coronavirus-2019.

5. Esakandari H, Nabi-Afjadi M, Fakkari-Afjadi J, Farahmandian N, Miresmaeili S-M, Bahreini E. A comprehensive review of COVID-19 characteristics. Biol Proced Online 2020;22:19, https://doi.org/10.1186/s12575-020-00128-2. 
6. Antunes R, Frontini R, Amaro N, Salvador R, Matos R, Morouço P, Rebelo-Gonçalves R. Exploring lifestyle habits, physical activity, anxiety and basic psychological needs in a sample of portuguese adults during covid-19. Int J Environ Res Public Health 2020; 17(12):4360, https://doi.org/10.3390/ijerph17124360.

7. Brooks SK, Webster RK, Smith LE, Woodland L, Wessely S, Greenberg N, Rubin GJ. The psychological impact of quarantine and how to reduce it: rapid review of the evidence. Lancet 2020;395(10227):912-920, https://doi.org/10.1016/S01406736(20)30460-8.

8. Bryan DC, Macdonald P, Ambwani S, Cardi V, Rowlands K, Willmott D, Treasure J. Exploring the ways in which COVID-19 and lockdown has affected the lives of adult patients with anorexia nervosa and their carers. Eur Eat Disorders Rev 2020;28(6):826835, https://doi.org/10.1002/erv.2762.

9. Martinez-Ferran M, Guía-Galipienso F, Sanchis-Gomar F, Pareja-Galeano H. Metabolic Impacts of Confinement during the COVID-19 Pandemic Due to Modified Diet and Physical Habits. Nutrients 2020;12(6):1549, https://doi.org/10.3390/nu12061549.

10. Raveendran AV, Jayadevan R. Reverse quarantine and COVID-19. Diabetes Metab Syndr 2020;14(5):1323-1325, https://doi.org/10.1016/j.dsx.2020.07.029.

11. Castañeda-Babarro A, Arbillaga-Etxarri A, Gutiérrez-Santamaría B, Coca A. Physical Activity Change during COVID-19 Confinement. Int J Environ Res Public Health 2020;17(18):6878, https://doi.org/10.3390/ijerph17186878.

12. Casagrande M, Favieri F, Tambelli R, Forte G. The enemy who sealed the world: effects quarantine due to the COVID-19 on sleep quality, anxiety, and psychological distress in the Italian $\quad$ population. Sleep $\quad$ Med 2020;75:1220, https://doi.org/10.1016/j.sleep.2020.05.011. 
13. Górnicka M, Drywień ME, Zielinska MA, Hamułka J. Dietary and Lifestyle Changes During COVID-19 and the Subsequent Lockdowns among Polish Adults: A CrossSectional Online Survey PLifeCOVID-19 Study. Nutrients 2020;12(8):2324, https://doi.org/10.3390/nu12082324.

14. Dubey S, Biswas P, Ghosh R, Chatterjee S, Dubey MJ, Chatterjee S, Lahiri D, Lavie CJ. Psychosocial impact of COVID-19. Diabetes Metab Syndr 2020;14(5):779-788, https://doi.org/10.1016/j.dsx.2020.05.035.

15. Di Renzo L, Gualtieri P, Pivari F, Soldati L, Attinà A, Cinelli G, Leggeri C, Caparello G, Barrea L, Scerbo F, et al. Eating habits and lifestyle changes during COVID-19 lockdown: an Italian survey. J Transl Med 2020;18(1):229, https://doi.org/10.1186/s12967-020-02399-5.

16. WHO - Food and nutrition tips during self-quarantine. World Health Organization. 2020. Available from: $\underline{\text { https://www.euro.who.int/en/health-topics/health- }}$ emergencies/coronavirus-covid19/publications-and-technical-guidance/food-andnutrition-tips-during-self-quarantine.

17. Romeo-Arroyo E, Mora M, Vázquez-Araújo L. Consumer behavior in confinement times: Food choice and cooking attitudes in Spain. Int J Gastron Food Sci 2020; 21:100226, https://doi.org/10.1016/j.ijgfs.2020.100226.

18. Ruíz-Roso MB, Padilha PC, Matilla-Escalante DC, Brun P, Ulloa N, Acevedo-Correa D, Peres WAF, Martorell M, Carrilho TRB, Cardoso LO, et al.. Changes of Physical Activity and Ultra-Processed Food Consumption in Adolescents from Different Countries during Covid-19 Pandemic: An Observational Study. Nutrients 2020;12(8):2289, https://doi.org/10.3390/nu12082289.

19. Ribeiro PVM, Andrade PA, Hermsdorff HHM, Santos CA, Cotta RMM, Estanislau JASG, Campos AAO, Rosa COB. Dietary non-nutrients in the prevention of non- 
communicable diseases: Potentially related mechanisms. Nutrition 2019;66:22-28, https://doi.org/10.1016/j.nut.2019.03.016.

20. Rocha DM, Bressan J, Hermsdorff HH. The role of dietary fatty acid intake in inflammatory gene expression: a critical review. Sao Paulo Med J 2017;135(2):157-168, http://dx.doi.org/10.1590/1516-3180.2016.008607072016.

21. Silveira BKS, Oliveira TMS, Andrade PA, Hermsdorff HHM, Rosa COB, Franceschini SCC. Dietary pattern and macronutrients profile on the variation of inflammatory biomarkers: scientific update. Cardiol Res Pract 2018;2018:4762575, https://doi.org/10.1155/2018/4762575.

22. Kriaucioniene V, Bagdonaviciene L, Rodríguez-Pérez C, Petkeviciene J. Associations between Changes in Health Behaviours and Body Weight during the COVID-19 Quarantine in Lithuania: The Lithuanian COVIDiet Study. Nutrients 2020;12(10):3119, https://doi.org/10.3390/nu12103119.

23. Sidor A, Rzymski P. Dietary choices and habits during COVID-19 lockdown: $\begin{array}{llll}\text { Experience } & \text { from } & \text { Poland. Nutrients }\end{array}$ https://doi.org/10.3390/nu12061657.

24. Jung UJ, Choi M-S. Obesity and its metabolic complications: the role of adipokines and the relationship between obesity, inflammation, insulin resistance, dyslipidemia and nonalcoholic fatty liver disease. Int J Mol Sci 2014;15(4):6184-223, https://doi.org/10.3390/ijms15046184.

25. Hermsdorff HHM, Zulet MA, Puchau B, Martínez JA. Fruit and vegetable consumption and proinflammatory gene expression from peripheral blood mononuclear cells in young adults: a translational study. Nutr Metab (Lond) 2010;7:42, https://doi.org/10.1186/1743-7075-7-42. 
26. Kim J, Nam J-H. Insight into the relationship between obesity-induced low-level chronic inflammation and COVID-19 infection. Int J Obes (Lond) 2020;44(7):1541-1542, https://doi.org/10.1038/s41366-020-0602-y.

27. Hajifathalian K, Kumar S, Newberry C, Shah S, Fortune B, Krisko T, Ortiz-Pujols S, Zhou XK, Dannenberg AJ, Kumar R, et al. Obesity is associated with worse outcomes in COVID-19: analysis of early data from New York City. Obesity (Silver Spring) 2020;28(9):1606-1612, https://doi.org/10.1002/oby.22923.

28. Kang Z, Luo S, Gui Y, Zhou H, Zhang Z, Tian C, Zhou Q, Wang Q, Hu Y, Fan H, et al. Obesity is a potential risk factor contributing to clinical manifestations of COVID-19. Int J Obes (Lond) 2020;44(12):2479-2485, https://doi.org/10.1038/s41366-020-00677-2.

29. Kwok S, Adam S, Hoong Ho J, Iqbal Z, Turkington P, Razvi S, Le Roux CW, Soran H, Syed AA. Obesity: A critical risk factor in the COVID-19 pandemic. Clin Obes 2020; 10(6):e12403, https://doi.org/10.1111/cob.12403.

30. Caci G, Albini A, Malerba M, Noonan DM, Pochetti P, Polosa R. COVID-19 and Obesity: Dangerous Liaisons. J Clin Med 2020;9(8):2511, https://doi.org/10.3390/jcm9082511.

31. Dietz W, Santos-Burgoa C. Obesity and its Implications for COVID-19 Mortality. Obesity (Silver Spring) 2020;28(6):1005, https://doi.org/10.1002/oby.22818.

32. Hussain A, Mahawar K, Xia Z, Yang W, El-Hasani S. Obesity and Mortality of COVID18 Meta-analysis. Obes Res Clin Pract 2020;14(4):295-300, https://doi.org/10.1016/j.orcp.2020.07.002.

33. Du R-H, Liang L-R, Yang C-Q, Wang W, Cao T-Z, Li M, Guo G-Y, Du J, Zheng C-L, Zhu Q, et al. . Predictors of Mortality for Patients with COVID-19 Pneumonia Caused by SARS-CoV-2: A Prospective Cohort Study. Eur Respir J 2020;55(5):2000524, https://doi.org/10.1183/13993003.00524-2020. 
34. Moola SMZ, Zachary M, Sears K, Sfetu M, Currie M, Lisy K, Tufanaru C, Qureshi R, Mattis P and Mu P. Systematic reviews of etiology and risk, In: Aromataris E, Munn Z (Editors). Joanna Briggs Institute Reviewer’s Manual. The Joanna Briggs Institute 2017.

35. Sterne JAC, Hernán MA, Reeves BC, Savović J, Berkman ND, Viswanathan M, Henry D, Altman DG, Ansari MT, Boutron I, et al. ROBINS-I: a tool for assessing risk of bias in non-randomised studies of interventions. BMJ 2016;355:i4919, https://doi.org/10.1136/bmj.i4919.

36. López-Moreno M, López MTI, Miguel M, Garcés-Rimón M. Physical and psychological effects related to food habits and lifestyle changes derived from covid-19 home confinement in the spanish population. Nutrients 2020;12(11):3445, https://doi.org/10.3390/nu12113445.

37. Jimenez A, Hollanda A, Palou E, Ortega E, Andreu A, Molero J, Mestre C, Ibarzabal A, Obach A, Flores L, et al. Psychosocial, Lifestyle, and Body Weight Impact of COVID19-Related Lockdown in a Sample of Participants with Current or Past History of Obesity in Spain. Obes Surg 2021;31(5):2115-2124, https://doi.org/10.1007/s11695-02105225-z.

38. Martínez-de-Quel O, Suárez-Iglesias D, López-Flores M, Pérez CA. Physical activity, dietary habits and sleep quality before and during COVID-19 lockdown: A longitudinal study. Appetite 2021;158:105019, https://doi.org/10.1016/j.appet.2020.

39. Rodríguez-Pérez C, Molina-Montes E, Verardo V, Artacho R, García-Villanova B, Guerra-Hernández EJ, Ruíz-López MD. Changes in dietary behaviours during the COVID-19 outbreak confinement in the Spanish COVIDiet study. Nutrients 2020; 12(6):1730, https://doi.org/10.3390/nu12061730.

40. Sánchez-Sánchez E, Ramírez-Vargas G, Avellaneda-López Y, Orellana-Pecino JI, García-Marín E, Díaz-Jimenez J. Eating Habits and Physical Activity of the Spanish 
Population during the COVID-19 Pandemic Period. Nutrients 2020;12(9):2826, https://doi.org/10.3390/nu12092826.

41. Barrea L, Pugliese G, Framondi L, Di Matteo R, Laudisio D, Savastano S, Colao A, Muscogiuri G. Does Sars-Cov-2 threaten our dreams? Effect of quarantine on sleep quality and body mass index. J Transl Med 2020;18(1):318, https://doi.org/10.1186/s12967-020-02465-y.

42. Cicero AFG, Fogacci F, Giovannini M, Mezzadri M, Grandi E, Borghi C, The Brisighella Heart Study Group. COVID-19-related quarantine effect on dietary habits in a northern italian rural population: Data from the brisighella heart study. Nutrients 2021;13(2):309, https://doi.org/10.3390/nu13020309.

43. Marchitelli S, Mazza C, Lenzi A, Ricci E, Gnessi L, Roma P. Weight Gain in a Sample of Patients Affected by Overweight /Obesity with and without a Psychiatric Diagnosis during the Covid-19 Lockdown. Nutrients 2020;12(11):3525, https://doi.org/10.3390/nu12113525.

44. Pellegrini M, Ponzo V, Rosato R, Scumaci E, Goitre I, Benso A, Belcastro S, Crespi C, De Michieli F, Ghigo E, et al. Changes in weight and nutritional habits in adults with obesity during the "lockdown" period caused by the COVID-19 virus emergency. Nutrients 2020;12(7):2016, https://doi.org/10.3390/nu12072016.

45. Scarmozzino F, Visioli F. Covid-19 and the subsequent lockdown modified dietary habits of almost half the population in an Italian sample. Foods 2020;9(5):675, https://doi.org/10.3390/foods9050675.

46. Błaszczyk-Bębenek E, Jagielski P, Bolesławska I, Jagielska A, Nitsch-Osuch A, Kawalec P. Nutrition behaviors in polish adults before and during COVID-19 lockdown. Nutrients 2020;12(10):3084, https://doi.org/10.3390/nu12103084. 
47. Grabia M, Markiewicz-Zukowska R, Puścion-Jakubik A, Bielecka J, Nowakowski P, Gromkowska-Kępka K, Mielcarek K, Socha K. The Nutritional and Health Effects of the COVID-19 Pandemic on Patients with Diabetes Mellitus. Nutrients 2020;12(10):3013, https://doi.org/10.3390/nu12103013.

48. Huber BC, Steffen J, Schlichtiger J, Brunner S. Altered nutrition behavior during COVID-19 pandemic lockdown in young adults. Eur $\mathbf{J}$ Nutr 2020;1:110, https://doi.org/10.1007/s00394-020-02435-6.

49. Poelman MP, Gillebaart M, Schlinkert C, Dijkstra SC, Derksen E, Mensink F, Hermans RCJ, Aardening P, de Ridder D, de Vet E. Eating behavior and food purchases during the COVID-19 lockdown: A cross-sectional study among adults in the Netherlands. Appetite 2021;157:105002, https://doi.org/10.1016/j.appet.2020.105002.

50. Jia P, Liu L, Xie X, Yuan C, Chen H, Guo B, Zhou J and Yang S. Impacts of COVID-19 lockdown on diet patterns among youths in Chine: the COVID-19 Impact on Lifestyle Chance Survey (COINLICS). Appetite 2021;158:105015, https://doi.org/10.1016/j.appet.2020.105015.

51. Zhao A, Li Z, Ke Y, Huo S, Ma Y, Zhang Y, Zhang J, Ren Z . Dietary diversity among chinese residents during the COVID-19 outbreak and its associated factors. Nutrients 2020;12(6):1699, https://doi.org/10.3390/nu12061699.

52. Zachary Z, Forbes B, Lopez B, Pedersen G, Welty J, Deyo A, Kerekes M. Selfquarantine and weight gain related risk factors during the COVID-19 pandemic. Obes Res Clin Pract 2020;14(3):210-216, https://doi.org/10.1016/j.orcp.2020.05.004.

53. Reyes-Olavarría D, Latorre-Román PA, Guzmán-Guzmán IP, Jerez-Mayorga D, Caamaño-Navarrete F, Delgado-Floody P. Positive and negative changes in food habits, physical activity patterns, and weight status during covid-19 confinement: Associated 
factors in the chilean population. Int J Environ Res Public Health 2020;17(15):5431, https://doi.org/10.3390/ijerph17155431.

54. Ismail LC, Osaili TM, Mohamad MN, Al Marzouqi A, Jarrar AH, Jamous DOA, Magriplis E, Ali HI, Al Sabbah H, Hasan H, et al. Eating Habits and Lifestyle during COVID-19 Lockdown in the United Arab Emirates: A Cross-Sectional Study. Nutrients 2020;12(11):3314, https://doi.org/10.3390/nu12113314.

55. Matsungo TM, Chopera P. Effect of the COVID-19 induced lockdown on nutrition, health and lifestyle patterns among adults in Zimbabwe. BMJ Nutr Prev Health 2020; 3(2):205-212, https://doi.org/10.1136/bmjnph-2020-000124.

56. Robinson E, Boyland E, Chisholm A, Harrold J, Maloney NG, Marty L, Mead BR, Noonan R, Hardman CA. Obesity, eating behavior and physical activity during COVID19 lockdown: A study of OK adults. Appetite 2021;156:104853, https://doi.org/10.1016/j.appet.2020.104853.

57. Werneck AO, Silva DR, Malta DC, Souza-Júnior PRB, Azevedo LO, Barros MBA, Szwarcwald CL. Lifestyle behaviors changes during the COVID-19 pandemic quarantine among 6,881 Brazilian adults with depression and 35,143 without depression. Ciênc saúde coletiva 2020;25:4151-4156, https://doi.org/10.1590/1413812320202510.2.27862020.

58. Ammar A, Brach M, Trabelsi K, Chtourou H, Boukhris O, Masmoudi L, Bouaziz B, Bentlage E, How D, Ahmed M, et al. Effects of COVID-19 Home Confinement on Eating Behaviour and Physical Activity: Results of the ECLB-COVID19 International Online Survey. Nutrients 2020;12(6):1583, https://doi.org/10.3390/nu12061583.

59. Iddir M, Brito A, Dingeo G, Del Campo SSF, Samouda H, La Frano MR, Bohn T. Strengthening the Immune System and Reducing Inflammation and Oxidative Stress 
through Diet and Nutrition: Considerations during the COVID-19 Crisis. Nutrients 2020; 12(6):1562, https://doi.org/10.3390/nu12061562.

60. FAO. Maintaining a healthy diet during the COVID-19 pandemic. 2020. - Food and Agriculture Organization of the United Nations. Available from: http://www.fao.org/3/ca8380en/CA8380EN.pdf.

61. Florindo H, Kleiner R, Vaskovich-Koubi D, Acúrcio RC, Carreira B, Yeini E, Tiram G, Liubomirski Y, Satchi-Fainaro R. Immune-mediated approaches against COVID-19. Nat Nanotechnol 2020;15(8):630-645, https://doi.org/10.1038/s41565-020-0732-3.

62. Calder PC. Nutrition, immunity and COVID-19. BMJ Nutr Prev Health 2020;3(1):7492, https://doi.org/10.1136/bmjnph-2020-000085.

63. Alkhatib A. Antiviral Functional Foods and Exercise Lifestyle Prevention of Coronavirus. Nutrients 2020;12(9):2633, https://doi.org/10.3390/nu12092633.

64. Coelho-Ravagnani CF, Corgosinho FC, Sanches FFZ, Prado CMM, Laviano A, Mota JF. Dietary recommendations during the COVID-19 pandemic. Nutr Rev 2021; 79(4):382-393, https://doi.org/10.1093/nutrit/nuaa067.

65. Cocate PG, Natali AJ, Alfenas RCG, de Oliveira A, dos Santos EC, Hermsdorff HHM. Carotenoid consumption is related to lower lipid oxidation and DNA damage in middleaged men. Br J Nutr 2015;114(2):257-64, https://doi.org/10.1017/S0007114515001622.

66. Cocate PG, Natali AJ, de Oliveira A, Longo GZ, Alfenas RCG, Peluzio MCG, dos Santos EC, Buthers JM, de Oliveira LL, Hermsdorff HHM. Fruit and vegetable intake and related nutrients are associated with oxidative stress markers in middle-aged men. Nutrition 2014;30(6):660-5, https://doi.org/10.1016/j.nut.2013.10.015.

67. De La Fuente M. Effects of antioxidants on immune system ageing. Eur J Clin Nutr 2002;56 Suppl 3:S5-8, https://doi.org/10.1038/sj.ejcn.1601476. 
68. Hermsdorff HHM, Zulet MA, Bressan J, Martínez JA. Efecto de la dieta en la inflamación crónica y de bajo grado relacionada con la obesidade y el síndrome metabólico. Endocrinol Nutr 2008;55(9):409-419, https://doi.org/10.1016/S15750922(08)75078-2.

69. Grant WB, Lahore H, McDonnell SL, Baggerly CA, French CB, Aliano JL, Bhattoa HP. Evidence that vitamin d supplementation could reduce risk of influenza and covid-19 infections and deaths. Nutrients 2020;12(4):988, https://doi.org/10.3390/nu12040988.

70. Lange KW, Nakamura Y. Lifestyle factors in the prevention of COVID-19. Glob Health J 2020;4(4):146-152, https://doi.org/10.1016/j.glohj.2020.11.002.

71. Tamara A, Tahapary DL. Obesity as a predictor for a poor prognosis of COVID-19: A systematic review. Diabetes Metab Syndr 2020;14(4):655-659, https://doi.org/10.1016/j.dsx.2020.05.020.

72. BRASIL. Guia alimentar para a população brasileira/Ministério da Saúde, Secretaria de Atenção à Saúde, Departamento de Atenção Básica. 2014. Available from: https://bvsms.saude.gov.br/bvs/publicacoes/guia_alimentar_populacao_brasileira_2ed.pd f.

73. Butler MJ, Barrientos RM. The impact of nutrition on COVID-19 susceptibility and long-term consequences. Brain Behav Immun 2020;87:53-54, https://doi.org/10.1016/j.bbi.2020.04.040.

74. Sami W, Ansari T, Butt NS, Ab Hamid MR. Effect of diet on type 2 diabetes mellitus: A review. Int J Health Sci (Qassim) 2017;11(2):65-71.

75. Guallar-Castillón P, Rodríguez-Artalejo F, Fornés NS, Banegas JR, Etxezarreta PA, Ardanaz E, Barricarte A, Chirlaque M-D, Iraeta MD, Larrañaga NL, et al. Intake of fried foods is associated with obesity in the cohort of Spanish adults from the European 
Prospective Investigation into Cancer and Nutrition. Am J Clin Nutr 2007;86(1):198205, https://doi.org/10.1093/ajcn/86.1.198.

76. Askari M, Heshmati J, Shahinfar H, Tripathi N, Daneshzad E. Ultra-processed food and the risk of overweight and obesity: a systematic review and meta-analysis of observational studies. Int J Obes (Lond) 2020;44(10):2080-2091, https://doi.org/10.1038/s41366-020-00650-z.

77. Meneguelli TS, Hinkelmann JV, Hermsdorff HHM, Zulet MA, Martínez JA, Bressan J. Food consumption by degree of processing and cardiometabolic risk: a systematic review. Int J Food Sci Nutr 2020;71(6):678-692, https://doi.org/10.1080/09637486.2020.1725961.

78. Rosenheck R. Fast food consumption and increased caloric intake: a systematic review of a trajectory towards weight gain and obesity risk. Obes Rev 2008;9(6):535-47, https://doi.org/10.1111/j.1467-789X.2008.00477.x.

79. Testino G, Pellicano R. Alcohol consumption in the COVID-19 era. Minerva Gastroenterol Dietol 2020;66(2):90-92, https://doi.org/10.23736/S1121-421X.20.026987.

80. Huang Y, Lu Y, Huang Y-M, Wang M, Ling W, Sui Y, Zhao H-L. Obesity in patients with COVID-19: a systematic review and meta-analysis. Metabolism 2020;113:154378, https://doi.org/10.1016/j.metabol.2020.154378.

81. Wang J, Zhu L, Liu L, Zhao X-A, Zhang Z, Xue L, Yan X, Huang S, Li Y, Cheng J, et al. Overweight and Obesity are Risk Factors of Severe Illness in Patients with COVID19. Obesity (Silver Spring) 2020;28(11):2049-2055, https://doi.org/10.1002/oby.22979.

82. Czernichow S, Beeker N, Rives-Lange C, Guerot E, Diehl J-L, Katsahian S, Hulot J-S, Poghosyan T, Carette C, Jannot A-S, et al. Obesity doubles mortality in patients hospitalized for (SARS-CoV-2) in Paris hospitals, France: a cohort study on 5,795 
patients. Obesity (Silver Spring) 2020;28(12):2282-2289, https://doi.org/10.1002/oby.23014.

83. Erener S. Diabetes, infection risk and COVID-19. Mol Metab 2020;39:101044, https://doi.org/10.1016/j.molmet.2020.101044.

84. Singh AK, Khunti K. Assessment of risk, severity, mortality, glycemic control and antidiabetic agents in patients with diabetes and COVID-19: A narrative review. Diabetes Res Clin Pract 2020;165:108266, https://doi.org/10.1016/j.diabres.2020.108266.

85. Penna PM, Hermsdorff HHM, Saron MLG. O papel de adipocinas na relação entre obesidade e resistência à insulina: uma revisão integrativa. Cadernos Unifoa 2020;15(42):131-141.

86. Miranda AES, Ferreira AVM, de Oliveira FLP, Hermsdorff HHM, Bressan J, Pimenta AM. Validation of metabolic syndrome and its self reported components in the cume study. Rev Min Enferm 2017;21:1-7. 
FIGURE 1. Flowchart based on the Preferred Reporting Items for Systematic Reviews and Meta-Analyses (PRISMA) (Moher et al. 2009).

* Other objectives: studies that did not contribute to the answer to the question raised in this review, those referring to food insecurity in this quarantine period, others that dealt with specific nutrients and not changes in food consumption in a more general way as proposed by this review.

FIGURE 2. Changes in food intake, eating behavior, and body weight during COVID19 quarantine. 
Table 1 Inclusion and exclusion criteria used in the search for articles.

\begin{tabular}{c}
\hline Criteria \\
Original articles \\
Inclusion \\
$\begin{array}{c}\text { Published in English, Portuguese or Spanish } \\
\text { Conducted with adolescents, adults, and } \\
\text { elderly individuals with or without } \\
\text { underlying diseases } \\
\text { Whose paper the main objective was to } \\
\text { assess the influence of quarantine on } \\
\text { changing eating habits and/or body weight }\end{array}$ \\
Studies conducted with children \\
Original studies with animals \\
Those that did not obtain relevant \\
information to clarify the guiding question
\end{tabular}


Table 2 Summary of studies concerning eating habits during COVID-19 quarantine

\begin{tabular}{|c|c|c|c|c|}
\hline Author / Year / Country & $\begin{array}{l}\text { Study } \\
\text { design }\end{array}$ & $\begin{array}{c}\text { Sample / } \\
\text { Sample size }\end{array}$ & Objective & Outcomes about eating habits \\
\hline $\begin{array}{l}\text { Ammar et al., } 2020 \\
\text { Europe, North-Africa, } \\
\text { Western Asia, and } \\
\text { American (58) }\end{array}$ & Cross-sectional & $\begin{array}{l}\text { Adults } \\
\text { individuals } \\
(\geq 18 \text { years }) \\
(\mathrm{n}=1.047)\end{array}$ & $\begin{array}{l}\text { To identify } \\
\text { changes in } \\
\text { mental health } \\
\text { and } \\
\text { multidimensional } \\
\text { lifestyle } \\
\text { behaviors during } \\
\text { the confinement } \\
\text { of the COVID- } \\
19\end{array}$ & 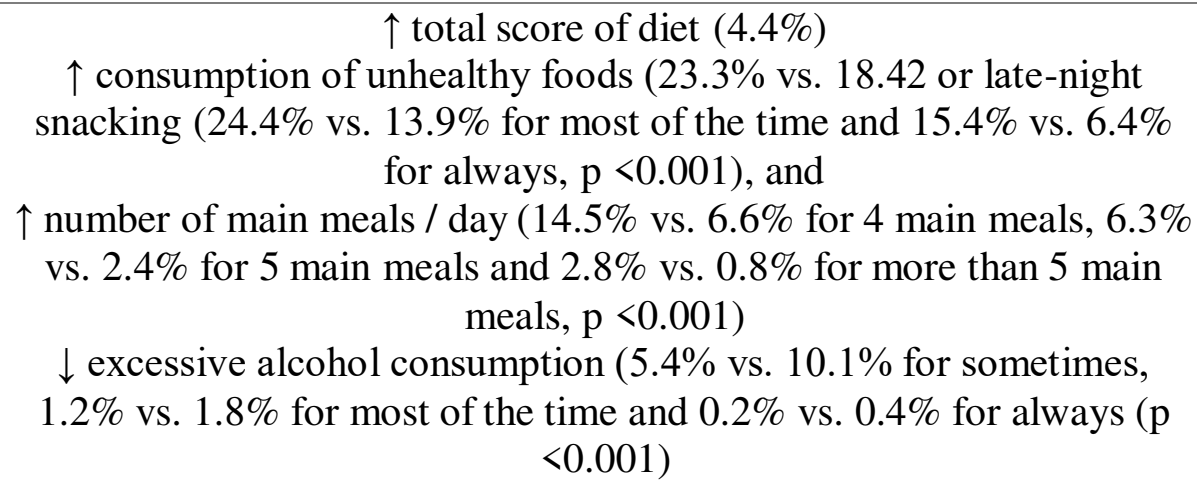 \\
\hline $\begin{array}{l}\text { Błaszczyk-Bebenek et al., } \\
2020 \\
\text { Poland (46) }\end{array}$ & Retrospective & $\begin{array}{c}\text { Adults } \\
\text { individuals } \\
(41.12 \pm \\
13.05 \text { years }) \\
(\mathrm{n}=312)\end{array}$ & $\begin{array}{l}\text { To describe the } \\
\text { potential effect } \\
\text { of social } \\
\text { isolation by } \\
\text { COVID-19 on } \\
\text { eating habits and } \\
\text { nutritional status } \\
\text { of adults } \\
\text { in Poland }\end{array}$ & 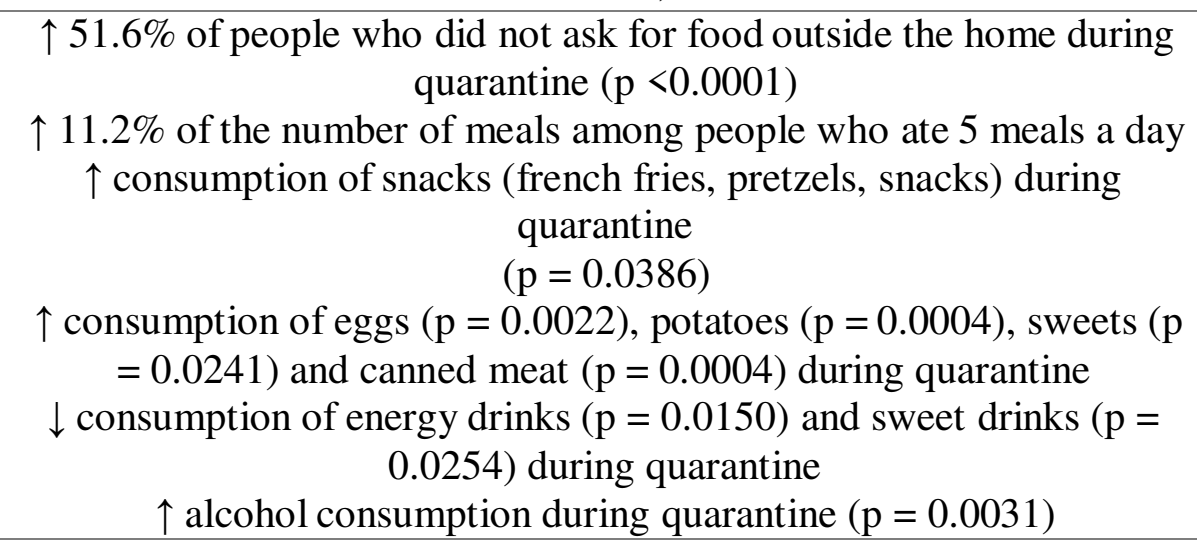 \\
\hline $\begin{array}{l}\text { Cicero et al., } 2021 \\
\text { Italy (42) }\end{array}$ & Longitudinal & $\begin{array}{l}\text { Adults and } \\
\text { elderly } \\
\text { individuals } \\
(64.6 \pm 13.3\end{array}$ & $\begin{array}{l}\text { To assess the } \\
\text { effect of } \\
\text { quarantine } \\
\text { related to }\end{array}$ & $\begin{array}{c}\uparrow \text { of food consumption }(32 \%) \\
\downarrow \text { of food consumption }(6.4 \%) \\
\text { No change in food consumption (50\%) }\end{array}$ \\
\hline
\end{tabular}


$\begin{array}{ccc}\text { years }) & \text { COVID on } & \uparrow \text { vegetables, healthy vegetable oils, and fruits, milk and yogurt, } \\ \text { (n=359) } & \text { smoking and } & \text { alcoholic beverages, }\end{array}$

eating habits of a rural population in northern Italy

Grabia et al., 2020 Poland (47)

Cross-sectional

Adults
individuals and people with diabetes (17-35 years) $(\mathrm{n}=124)$ $\downarrow$ fish, mussels, crustaceans, and legumes coffee, sugars and sweets, low-fat meats, eggs, nuts
To assess the impact of the COVID-19 pandemic on nutrition

and health behaviors of patients with DM

behaviors of
patients with DM

Huber et al., 2020

Germany (48)

Cross-sectional

Young
individuals
and adults
$(23.3 \pm 4.0$
years $)$
$(\mathrm{n}=1.980)$

To explore how
food
consumption
changed during
confinement and
determine what
factors impacted
those changes

$\uparrow$ healthy eating (60\%)
$\uparrow$ regular meals, mainly the main meals (65\%)

$\uparrow$ snacks (30\%)
$\uparrow$ water (48\%)
$\uparrow$ fruit (44\%)

$\uparrow$ vegetables $(40 \%)$

$\uparrow$ grains $(37 \%)$

$\downarrow$ fast food $(32 \%)$

$\downarrow$ convenience food $(29 \%)$

$\downarrow$ snacks $(29 \%)$

$\downarrow$ red meat $(22 \%)$

$\downarrow$ sweets $(22 \%)$

$\downarrow$ visits to restaurants (46.4\% vs $1.9 \%)$ and coffee shops (48.5\% vs

$2.5 \%$ ) during quarantine

$\downarrow$ food orders by delivery $(51.8 \%)$

$\downarrow$ consumption of ready-made foods ( $18.0 \%$ vs $16.0 \%)$,

influenced by $\uparrow$ in physical activities (OR 2.30 [95\% CI 1.42-3.84], (p $<0.01)$ and a quantity reduced amount of food during quarantine (OR, 1.64 [95\% CI 1.04-2.55], $\mathrm{p}=0.03$ )

No change in the amount of food $(52.1 \%)$ in individuals with a BMI

$<20 \mathrm{~kg} / \mathrm{m}^{2}$, eutrophic BMI, and $>25 \mathrm{~kg} / \mathrm{m}^{2}$

$\uparrow$ of consumption in the amount of food $(31.2 \%)$, more frequent in women (32.8\% vs $26.6 \%$ ) and in the age group of $17-25$ years and those with $\uparrow$ of alcohol consumption

(42.3\%), smoking (42.0\%) and mental stress (35.4\%) 
$\downarrow$ consumption in the amount of food (16.8\%), in those with the greater practice of physical activities (OR, 1.9 [CI 1.3-2.8])

$\uparrow$ confectionery products $(64.4 \%$ in those with $\uparrow$ in general consumption and $25.0 \%$ in those with $\downarrow$ in general consumption) $\uparrow$ bread (46.8\%) among people with $\uparrow$ of general consumption

Ismail et al., 2020 United Arab Emirates (54)
Cross-sectional

Cross-sectional

Adults
individuals
$(18-55+)$

$(\mathrm{n}=1.012)$
To investigate the effect of quarantine on eating habits, physical activity, stress and sleep behaviors among UAE adult residents

$$
\uparrow \text { meat }(24.5 \%)
$$

$\uparrow$ home cooked meals $(82.8 \%$ vs $96.2 \%)(\mathrm{p}<0.001)$

$$
\downarrow \text { fast food }(\mathrm{p}<0.001)
$$

$\uparrow$ number of 5 or more meals per day $(2.1 \%$ vs $7 \%)(\mathrm{p}<0.001)$

$\uparrow$ breakfast $(66 \%$ vs $74.2 \%)(\mathrm{p}<0.001)$

$\downarrow$ of those who skipped breakfast $(64.2 \%$ vs $46.2 \%)$ and reported that

it was due to lack of time before quarantine $(62.3 \%)$ and lack of appetite $(36 \%)$

$\uparrow$ water consumption $(24.1 \%$ vs $27.8 \%)(\mathrm{p}=0.003)$

No consumption of fruits (51.2\%) and vegetables (37\%) and milk and dairy products $(46.2 \%)$ daily

Consumption of sweets and desserts $(46.1 \%)$ and snacks, cookies, and nuts $(37.1 \%)$ every day

Consumption of coffee and tea at least once a day (69.2\%)

Without energy drink consumption (86.5\%)

\begin{tabular}{|c|c|c|c|c|}
\hline $\begin{array}{c}\text { Jia et al., } 2020 \\
\text { China (50) }\end{array}$ & Retrospective & $\begin{array}{c}\text { Young } \\
\text { individuals } \\
\text { and adults } \\
(15-28 \text { years }) \\
(\mathrm{n}=10.082)\end{array}$ & $\begin{array}{l}\text { To assess } \\
\text { changes in } \\
\text { dietary patterns } \\
\text { among } \\
\text { young people in } \\
\text { China under the } \\
\text { COVID-19 } \\
\text { block, based on }\end{array}$ & $\begin{array}{c}\downarrow \text { rice, meat, poultry, vegetables, fruits, soy products, and dairy } \\
\text { products ( } \mathrm{p}<0.05 \text { ) } \\
\uparrow \text { higher of rice, vegetables, and fruits by women and dairy less } \\
\text { frequently } \\
\uparrow \text { the higher consumption of wheat and vegetable products by men } \\
\uparrow \text { of the higher consumption of rice by graduate students, when } \\
\text { compared to those of high school and undergraduate } \\
\uparrow \text { the higher consumption of canned vegetables by undergraduate }\end{array}$ \\
\hline
\end{tabular}

Lower consumption of sweet drinks and fruit juices, compared to other drinks $(44.2 \%)$ 


\begin{tabular}{|c|c|c|c|c|}
\hline & & & $\begin{array}{l}\text { the impact of } \\
\text { COVID-19 on } \\
\text { lifestyle } \\
\text { Change Survey } \\
\text { (COINLICS) }\end{array}$ & $\begin{array}{c}\text { students } \\
\downarrow \text { consumption of beverages by women, at all educational levels } \\
\uparrow \text { tea }(14.8 \% \text { vs } 19.5 \%)(\mathrm{p}>0.01) \text {, by women between high school } \\
(12.9 \% \text { vs } 19.0 \%)(\mathrm{p}<0.01) \text { and undergraduate students }(11.5 \% \text { vs } \\
16.1 \%)(\mathrm{p}<0.01)\end{array}$ \\
\hline $\begin{array}{l}\text { Jimenez et al., } 2021 \\
\text { Spain (37) }\end{array}$ & Cross-sectional & $\begin{array}{l}\text { Adults and } \\
\text { elderly } \\
\text { patients with } \\
\text { a current or } \\
\text { past history } \\
\text { of obesity } \\
(\geq 18 \text { years) } \\
\text { ( } \mathrm{n}=603) \\
\text { Only } 42.7 \% \\
\text { reported their } \\
\text { current body } \\
\text { weight and } \\
\text { body mass } \\
\text { index (BMI) }\end{array}$ & $\begin{array}{l}\text { To assess the } \\
\text { impact that the } \\
\text { COVID-19- } \\
\text { related lockdown } \\
\text { ( } 9 \text { weeks after } \\
\text { the stay-at-home } \\
\text { order) had on the } \\
\text { factors } \\
\text { psychosocial, } \\
\text { lifestyle, and } \\
\text { body weight } \\
\text { among patients } \\
\text { with a present or } \\
\text { past history of } \\
\text { severe obesity }\end{array}$ & $\begin{array}{c}\text { Changed dietary habits }(32.5 \%) \\
75 \% \text { and } 81.4 \% \text { not or slightly changed consumption the sugary } \\
\text { beverages and alcohol, respectively } \\
\uparrow \text { snacking (19\%) } \\
\text { non-bariatric and bariatric }>2 \text { y patients had more negative changes in } \\
\text { regular dietary behaviors, and } \uparrow \text { likelihood of weight gain compared } \\
\text { with bariatric }\end{array}$ \\
\hline $\begin{array}{c}\text { Kriaucioniene et al., } 2020 \\
\text { Lithuania (22) }\end{array}$ & Cross-sectional & $\begin{array}{l}\text { Adults and } \\
\text { elderly } \\
\text { individuals } \\
(\geq 18 \text { years }) \\
(\mathrm{n}=2.447)\end{array}$ & $\begin{array}{l}\text { To investigate } \\
\text { the effect of the } \\
\text { COVID-19 } \\
\text { quarantine on } \\
\text { dietary, physical } \\
\text { activity, and } \\
\text { alcohol } \\
\text { consumption } \\
\text { habits of } \\
\text { Lithuanians and }\end{array}$ & $\begin{array}{c}\text { Ate more than usual }(49.4 \%) \\
\uparrow \text { snacking }(45.1 \%) \\
\uparrow \text { consumption of fried food }(20.6 \%), \text { homemade pastries }(37.7 \%), \\
\text { vegetables }(18.8 \%) \text { and fruits }(22.1 \%) \text {; and } \downarrow \text { consumption of fast } \\
\text { foods }(41.3 \%) \text {, carbonated and sugary drinks }(19.4 \%) \text {, commercial } \\
\text { pastries (26\%), vegetables (15\%) and fruits }(14.7 \%) \\
\text { No changes in the intake of alcoholic beverages }(69.9 \%) \\
\downarrow \text { alcoholic beverages }(15.9 \%) \\
\uparrow \text { alcoholic beverages }(14.2 \%)\end{array}$ \\
\hline
\end{tabular}


the association

between health

behavior and

weight changes

\begin{tabular}{|c|c|c|c|c|}
\hline $\begin{array}{l}\text { López-Moreno et al., } 2020 \\
\text { Spain (36) }\end{array}$ & Cross-sectional & $\begin{array}{l}\text { Adults and } \\
\text { elderly } \\
\text { individuals } \\
(39.1 \pm 12.9 \\
\text { years }) \\
(\mathrm{n}=675)\end{array}$ & $\begin{array}{l}\text { To evaluate the } \\
\text { effects of } \\
\text { COVID-19 home } \\
\text { confinement on } \\
\text { the food habits, } \\
\text { lifestyle, and } \\
\text { emotional } \\
\text { balance }\end{array}$ & $\begin{array}{c}\text { Changed dietary habits }(54.4 \%) \\
\uparrow \text { food intake }(19.6 \%), \downarrow \text { food intake }(33.3 \%) \\
\uparrow \text { purchase of snacks (39\%) and processed foods }(25 \%) \\
\uparrow \text { fresh food consumption }(55.7 \%) \\
\uparrow \text { number of meals/day }-5 \text { meals / day }(1 \% \text { vs } 23 \%) \\
\uparrow \text { alcoholic beverages }(18.3 \%)\end{array}$ \\
\hline $\begin{array}{l}\text { Matsungo and } \\
\text { Chopera, } 2020 \\
\text { Zimbabwe (55) }\end{array}$ & Cross-sectional & $\begin{array}{c}\text { Adults } \\
\text { individuals } \\
(\geq 18 \text { years }) \\
(\mathrm{n}=507)\end{array}$ & $\begin{array}{l}\text { To investigate } \\
\text { the impacts of } \\
\text { the COVID-19 } \\
\text { lockdown on } \\
\text { nutrition, } \\
\text { physical activity, } \\
\text { and lifestyle } \\
\text { patterns }\end{array}$ & $\begin{array}{c}\text { Changed diet and consumption patterns }(96.6 \%) \\
\downarrow \text { consumption of the food groups 'other vitamin A-rich fruits and } \\
\text { vegetables' }(57.8 \%), \text { 'other vegetable' }(48.5 \%) \text {, 'other fruits' } \\
(64.9 \%) \text {, 'nuts and seeds' }(45 \%) \text {, 'cereals breads and tubers' }(41.1 \%) \text {, } \\
\text { and 'dairy products' }(44.9 \%), \uparrow \text { consumption of 'dark green leafy } \\
\text { vegetables' }(33.72 \%) \\
\downarrow \text { alcohol consumption }(53.3 \%)\end{array}$ \\
\hline $\begin{array}{l}\text { Pellegrini et al., } 2020 \\
\text { Italy (44) }\end{array}$ & $\begin{array}{l}\text { Retrospective } \\
\text { observational }\end{array}$ & $\begin{array}{l}\text { Adults } \\
\text { individuals } \\
\text { undergoing } \\
\text { weight loss } \\
(47.9 \pm 16 \\
\text { years }) \\
(\mathrm{n}=150)\end{array}$ & $\begin{array}{l}\text { To evaluate } \\
\text { changes in } \\
\text { weight and } \\
\text { eating habits } \\
\text { among } \\
\text { individuals with } \\
\text { obesity treated in } \\
\text { a weight loss } \\
\text { program after } 1 \\
\text { month of }\end{array}$ & $\begin{array}{c}\text { Ate more than before quarantine (40\%) } \\
\uparrow \text { number of snacks }(32.7 \%) \\
\downarrow \text { consumption of fruit and vegetables }(18 \%) \\
\uparrow \text { consumption of fruit and vegetables }(27.3 \%) \\
\uparrow \text { fresh food }(20.7 \%) \\
\uparrow \text { sweets consumption }(50 \%) \\
\text { Factors that impacted eating habits: boredom/solitude }(36 \%), \\
\text { Anxiety/depression }(34.7 \%) \text {, and more time for cooking }(32.7 \%)\end{array}$ \\
\hline
\end{tabular}




\begin{tabular}{|c|c|c|c|c|}
\hline & & & $\begin{array}{l}\text { lockdown due to } \\
\text { the COVID-19 }\end{array}$ & \\
\hline $\begin{array}{l}\text { Poelman et al., } 2021 \\
\text { Netherlands (49) }\end{array}$ & Cross-sectional & $\begin{array}{l}\text { Adults and } \\
\text { elderly } \\
\text { individuals } \\
(49.9 \pm 17.0 \\
\text { years }) \\
(\mathrm{n}=1.030)\end{array}$ & $\begin{array}{l}\text { To examine self- } \\
\text { reported eating } \\
\text { behavior and } \\
\text { food purchases } \\
\text { during five } \\
\text { weeks into the } \\
\text { COVID-19 } \\
\text { lockdown }\end{array}$ & $\begin{array}{c}83.3 \% \text { of the participants no changed dietary habits } \\
\text { Ate more than usual }(8.9 \%) \\
\uparrow \text { eating unhealthier }(7.1 \%) \\
\uparrow \text { eating healthier }(9.6 \%) \\
\uparrow \text { sweets and snacks consumption }(22.1 \%) \\
\text { Factors contributed to eating unhealthier during lockdown: facing } \\
\text { more unhealthy temptations at home (35.6\%), more leisure time } \\
\text { (31.5\%), being bored (21.9\%), and more stress }(19.2 \%) \\
\text { Individuals with overweight and obesity were more likely to indicate } \\
\text { to eat unhealthier and eat more than usual } \\
\text { during lockdown compared to individuals with a healthy weight }\end{array}$ \\
\hline $\begin{array}{c}\text { Reyes-Olavarría et al., } \\
2020 \\
\text { Chile (53) }\end{array}$ & Cross-sectional & $\begin{array}{l}\text { Adults and } \\
\text { elderly } \\
\text { individuals } \\
(18-62 \text { years }) \\
(\mathrm{n}=700)\end{array}$ & $\begin{array}{l}\text { To determine } \\
\text { changes in eating } \\
\text { habits and } \\
\text { physical activity } \\
\text { caused by } \\
\text { confinement } \\
\text { during the } \\
\text { COVID-19 } \\
\text { pandemic and } \\
\text { analyze their } \\
\text { associations with } \\
\text { changes in body } \\
\text { weight and } \\
\text { physical activity }\end{array}$ & $\begin{array}{c}\text { Ate more than before }(51.3 \%) \\
\text { Less healthy than before }(26.7 \%) \\
\text { Healthier than before }(33.7 \%) \\
\downarrow \text { consumption of vegetables and fruits }(20.7 \%) \\
\uparrow \text { consumption of vegetables and fruits }(30.9 \%)\end{array}$ \\
\hline
\end{tabular}




\begin{tabular}{|c|c|c|c|c|}
\hline $\begin{array}{l}\text { Robinson et al., } 2021 \\
\text { United Kingdom (56) }\end{array}$ & Cross-sectional & $\begin{array}{l}\text { Adults } \\
\text { individuals } \\
(\geq 18 \text { years }) \\
(\mathrm{n}=2.002)\end{array}$ & $\begin{array}{c}\text { To examine } \\
\text { weight-related } \\
\text { behaviors, } \\
\text { weight } \\
\text { management } \\
\text { barriers, physical } \\
\text { activity levels, } \\
\text { diet quality, and } \\
\text { problematic } \\
\text { overeating } \\
\text { during the } \\
\text { COVID-19 } \\
\text { lockdown }\end{array}$ & $\begin{array}{c}\uparrow \uparrow \text { snacked }(56 \%) \\
\text { Factors significantly associated with lower diet quality: being younger, } \\
\text { lower in education, and higher BMI }(\mathrm{p}<0.001) \\
\text { Factors significantly associated with increased overeating: being } \\
\text { younger, lower in education, previous psychiatric diagnosis, and } \\
\text { higher BMI }\end{array}$ \\
\hline $\begin{array}{l}\text { Rodríguez-Pérez et al., } \\
2020 \\
\text { Spain (39) }\end{array}$ & Cross-sectional & $\begin{array}{l}\text { Adults and } \\
\text { elderly } \\
\text { individuals } \\
(21-65 \text { years }) \\
(\mathrm{n}=7.514)\end{array}$ & $\begin{array}{l}\text { To examine } \\
\text { whether } \\
\text { confinement } \\
\text { during the } \\
\text { COVID-19 } \\
\text { influenced the } \\
\text { eating habits of } \\
\text { the Spanish adult } \\
\text { population }\end{array}$ & $\begin{array}{c}\uparrow \text { healthier eating habits }(\mathrm{p} \text {-value }=<0.001) \\
\qquad \text { alcohol intake }(57.3 \%) \\
\text { The majority stated that they were no longer eating during } \\
\text { confinement }(63.7 \%) \text { and that they kept eating fried foods }(73 \%)\end{array}$ \\
\hline $\begin{array}{l}\text { Romeo-Arroyo et al., } 2020 \\
\text { Spain (17) }\end{array}$ & Cross-sectional & $\begin{array}{l}\text { Adults and } \\
\text { elderly } \\
\text { individuals } \\
(42.58 \pm \\
12.25 \text { years }) \\
(\mathrm{n}=600)\end{array}$ & $\begin{array}{l}\text { To assess the } \\
\text { perception of } \\
\text { consumers } \\
\text { concerning their } \\
\text { food choices and } \\
\text { habits during the } \\
\text { period of } \\
\text { confinement due }\end{array}$ & $\begin{array}{c}\downarrow \text { consumption of vegetables, meats, fruits, pasta, rice, bread, cereals, } \\
\text { fish, sausage, dairy products, alcoholic beverages, and sweets (30\%) } \\
\downarrow \text { sweets consumption (50\%) }\end{array}$ \\
\hline
\end{tabular}


to the COVID-19
Ruiz-Roso et al., 2020 Italy, Spain, Chile,

Colombia, and Brazil (18)
Cross-sectional

Adolescents

(10-19 years)

$(\mathrm{n}=820)$
To investigate

the nutritional

changes during

the COVID-19

quarantine $\uparrow$ vegetables and fruits consumption (35.2\% and $25.5 \%$ before and $43 \%$ and $33.2 \%$ during quarantine)

$\downarrow$ fast food consumption during quarantine (44.6\% consumed less than once a week before and $64 \%$ during quarantine)

$\uparrow$ sweets consumption ( $14 \%$ before and $20.7 \%$ during confinement)

$\uparrow$ fried food consumption (4-7 days a week, from $7.4 \%, 3.7 \%, 1.8 \%$ and $2.1 \%$ before to $8.8 \%, 3.8 \%, 2.2 \%$ and $2.9 \%$ during confinement)

Ruiz-Roso et al., 2020 Spain (2)

Cross-sectional

Adults, elderly individuals

whit type 2 diabetes mellitus

(45-77 years) $(\mathrm{n}=72)$
To examine the impact of

lockdown during the COVID-19

on eating and

exercise habits,

as well as the

psychological effects in

patients with

type 2 diabetes

mellitus

\section{Sánchez-Sánchez et al., \\ Adolescent, \\ To evaluate the} 2020 Spain (40)

Cross-sectional
Descriptive

adult, and elderly individuals

$(38.7 \pm 12.4$ years)

$(n=1.065)$ eating habits,

consumption,

and physical

activity before

and after a

COVID-19

confinement $\uparrow$ consumption of dairy products $(\mathrm{p}<0.005)$, vegetables $(\mathrm{p}<0.0001)$, snacks $(\mathrm{p}<0.001)$ and sugary foods $(\mathrm{p}<0.0001)$ during the lockdown

$\uparrow$ snack consumption $\geq 4$ times/week $(12.9 \%)$

$\uparrow$ vegetable consumption $\geq 2$ times / day $(40 \%)$

No change in the consumption of drinks with sugar, nuts, cereals, legumes, fruits, meat, fish, and eggs

Patients with BMI (35 to $40 \mathrm{~kg} / \mathrm{m}^{2}$ ) significantly $\uparrow$ sugary food consumption $(\mathrm{p}=0.001)$

Women and higher BMI $\uparrow$ food craving

$\uparrow$ consumption of snacks, vegetables, dairy products, and fruits correlated with food cravings 


\begin{tabular}{|c|c|c|c|c|}
\hline $\begin{array}{c}\text { Werneck et al., } 2020 \\
\text { Brazil (57) }\end{array}$ & Cross-sectional & $\begin{array}{c}\text { Adults } \\
\text { individuals } \\
\text { with } \\
\text { depression or } \\
\text { without } \\
\text { depression } \\
(\geq 18 \text { years }) \\
(\mathrm{n}=41.923)\end{array}$ & $\begin{array}{l}\text { To analyze the } \\
\text { association } \\
\text { between } \\
\text { previously } \\
\text { diagnosed } \\
\text { lifetime } \\
\text { depression and } \\
\text { changes in } \\
\text { physical activity, } \\
\text { TV-viewing, } \\
\text { consumption of } \\
\text { fruits and } \\
\text { vegetables as } \\
\text { well as the } \\
\text { frequency of } \\
\text { ultra-processed } \\
\text { food } \\
\text { consumption } \\
\text { during the } \\
\text { COVID-19 } \\
\text { quarantine }\end{array}$ & $\begin{array}{l}\text { Individuals without and with depression, } \\
\text { respectively, presented a considerable incidence of low frequency of } \\
\text { fruit or vegetable consumption [28.3\% (95\% CI: } 25.8 \text { to } 31.0) \text { vs } 31.5 \% \\
\text { (95\% CI: } 26.1 \text { to } 37.5)] \text { and } \\
\text { elevated frequency of ultra-processed food consumption } \\
\text { [9.7\% (95\%CI: } 8.9 \text { to } 10.7) \text { vs } 15.2 \% \\
\text { (95\% CI: } 13.0 \text { to } 17.7)] \\
\text { People with depression were } 49 \% \text { more likely to } \\
\text { elevated frequency of ultra-processed food consumption } \\
\text { incidence [OR: } 1.49 \text { (95\% CI: } 1.21 \text { to } \\
1.83)] \text { when compared with people without depression }\end{array}$ \\
\hline $\begin{array}{l}\text { Zhao et al., } 2020 \\
\text { China (51) }\end{array}$ & Cross-sectional & $\begin{array}{c}\text { Adults and } \\
\text { elderly } \\
\text { individuals } \\
(18-80 \text { years }) \\
(\mathrm{n}=1,938)\end{array}$ & $\begin{array}{l}\text { To assess food } \\
\text { diversity among } \\
\text { Chinese } \\
\text { residents during } \\
\text { the isolation } \\
\text { period by } \\
\text { COVID-19 and } \\
\text { explore the as } \\
\text { sociated factors }\end{array}$ & $\begin{array}{c}\uparrow \text { consumption of the cereal group }(97.8 \%) ; \downarrow \text { consumption of the } \\
\text { group of fish }(57.2 \%) \text {, legumes }(70.1 \%) \text {, and miscellaneous }(56.9 \%) \\
\text { The age group between } 18 \text { and } 45 \text { years had a lower food diversity } \\
\text { score } \\
\text { Individuals living in locations where confirmed cases of Covid-19 by } \\
\text { the laboratory were }>500 \text { cases or living in Hubei province had a } \\
\text { lower dietary diversity (lower HDDS) }\end{array}$ \\
\hline
\end{tabular}


Table 3 Summary of studies concerning body weight changes during COVID-19 quarantine

\begin{tabular}{|c|c|c|c|c|}
\hline Author / Year / Country & Study design & $\begin{array}{c}\text { Sample / } \\
\text { Sample size }\end{array}$ & Objective & Outcomes about weight \\
\hline $\begin{array}{c}\text { Barrea et al., } 2020 \\
\text { Italy (41) }\end{array}$ & Cross-sectional & $\begin{array}{l}\text { Adults and } \\
\text { overweight } \\
\text { individuals } \\
(44.9 \pm 13.3 \\
\text { years }) \\
(\mathrm{n}=121)\end{array}$ & $\begin{array}{l}\text { To investigate } \\
\text { the effect of } \\
\text { COVID-19 } \\
\text { quarantine in the } \\
\text { sleep quality and } \\
\text { body mass index } \\
\text { for Italian adults }\end{array}$ & $\begin{array}{c}\uparrow \text { BMI in both sexes }(\mathrm{p}<0.001) \\
\uparrow \text { significant BMI in eutrophic individuals }(\mathrm{p}=0.023) \text {, individuals with } \\
\text { grade I obesity }(\mathrm{p}=0.027) \text {, grade II obesity }(\mathrm{p}=0.020) \text { and with no } \\
\text { significant differences between those with overweight }(\mathrm{p}=0.215) \text { and } \\
\text { grade III obesity }(\mathrm{p}=0.871)\end{array}$ \\
\hline $\begin{array}{l}\text { Błaszczyk-Bebenek et al., } \\
2020 \\
\text { Poland (46) }\end{array}$ & Retrospective & $\begin{array}{l}\text { Adults } \\
\text { individuals } \\
(41.12 \pm 13.05 \\
\text { years }) \\
(\mathrm{n}=312)\end{array}$ & $\begin{array}{l}\text { To describe the } \\
\text { potential effect } \\
\text { of social } \\
\text { isolation by } \\
\text { COVID-19 on } \\
\text { eating habits and } \\
\text { nutritional status } \\
\text { of adults } \\
\text { in Poland }\end{array}$ & $\begin{array}{l}\uparrow \text { body weight from } 73.47 \mathrm{~kg} \text { to } 74.03 \mathrm{~kg}(\mathrm{p}<0.0001) \\
\uparrow \mathrm{BMI} \text { from } 24.98 \mathrm{~kg} / \mathrm{m}^{2} \text { to } 25.28 \mathrm{~kg} / \mathrm{m}^{2}(\mathrm{p}<0.0001)\end{array}$ \\
\hline $\begin{array}{l}\text { Ismail et al., } 2020 \\
\text { Abu Dabhi, Dubai, } \\
\text { Sharjah, and Northern } \\
\text { Emirates (54) }\end{array}$ & Cross-sectional & $\begin{array}{l}\text { Adult } \\
\text { individuals } \\
(18 \text { to } 55+) \\
(\mathrm{n}=1.012)\end{array}$ & $\begin{array}{l}\text { To investigate } \\
\text { the effect of } \\
\text { quarantine on } \\
\text { eating habits, } \\
\text { physical } \\
\text { activity, stress } \\
\text { and } \\
\text { sleep behaviors } \\
\text { among UAE }\end{array}$ & $\begin{array}{c}\uparrow \text { weight }(40.1 \%) \text {, especially among those aged }>36 \text { years }(\mathrm{p}=0.042) \\
\text { and who reported a greater number of meals }(\mathrm{p}=0.024) \\
\text { Weight maintenance }(7.9 \%)\end{array}$ \\
\hline
\end{tabular}


adult residents

\begin{tabular}{|c|c|c|c|c|}
\hline $\begin{array}{l}\text { Jimenez et al., } 2021 \\
\text { Spain (37) }\end{array}$ & Cross-sectional & $\begin{array}{l}\text { Adults and } \\
\text { elderly patients } \\
\text { with a current } \\
\text { or past history } \\
\text { of obesity } \\
(\geq 18 \text { years }) \\
(\mathrm{n}=603) \\
\text { Only } 42.7 \% \\
\text { reported their } \\
\text { current body } \\
\text { weight and } \\
\text { body mass } \\
\text { index (BMI) }\end{array}$ & $\begin{array}{l}\text { To assess the } \\
\text { impact that the } \\
\text { COVID-19- } \\
\text { related } \\
\text { lockdown (9 } \\
\text { weeks after the } \\
\text { stay-at-home } \\
\text { order) had on } \\
\text { the factors } \\
\text { psychosocial, } \\
\text { lifestyle, and } \\
\text { body weight } \\
\text { among patients } \\
\text { with a present or } \\
\text { past history of } \\
\text { severe obesity }\end{array}$ & $\begin{array}{c}\uparrow \text { weight }(52.2 \%) \\
\text { Participants with weight gain rated higher for changes in mood ( } \mathrm{p}< \\
0.01) \text {, sleep }(\mathrm{p}<0.01) \text {, changes of dietary habits }(\mathrm{p}<0.01) \text {, purchase of } \\
\text { unhealthy and comfort foods }(\mathrm{p}<0.01) \text {, increase in consumption of } \\
\text { sugary beverages }(\mathrm{p}<0.01) \text { or alcohol }(\mathrm{p}<0.01) \text {, and snacking }(\mathrm{p}< \\
0.01) \text { than those without weight gain }\end{array}$ \\
\hline $\begin{array}{l}\text { Kriaucioniene et al., } 2020 \\
\text { Lithuania (22) }\end{array}$ & Cross-sectional & $\begin{array}{l}\text { Adults and } \\
\text { elderly } \\
\text { individuals } \\
(\geq 18 \text { years }) \\
(\mathrm{n}=2.447)\end{array}$ & $\begin{array}{l}\text { To investigate } \\
\text { the effect of the } \\
\text { COVID-19 } \\
\text { quarantine on } \\
\text { dietary, physical } \\
\text { activity, and } \\
\text { alcohol } \\
\text { consumption } \\
\text { habits of }\end{array}$ & $\begin{array}{c}\text { 个 weight }(31.5 \%) \\
\text { Maintenance or didn't know }(68.5 \%) \\
\text { Weight gain was significantly associated with } \uparrow \text { intake of carbonated or } \\
\text { sugary drinks, homemade pastries, and fast food; } \uparrow \text { snacking; eat more } \\
\text { than usual; } \downarrow \text { physical activity, and higher BMI }\end{array}$ \\
\hline
\end{tabular}




\begin{tabular}{|c|c|c|c|c|}
\hline & & & $\begin{array}{l}\text { Lithuanians and } \\
\text { the association } \\
\text { between health } \\
\text { behavior and } \\
\text { weight changes }\end{array}$ & \\
\hline $\begin{array}{l}\text { López-Moreno et al., } 2020 \\
\text { Spain (36) }\end{array}$ & Cross-sectional & $\begin{array}{l}\text { Adults and } \\
\text { elderly } \\
\text { individuals } \\
(39.1 \pm 12.9 \\
\text { years }) \\
(\mathrm{n}=675)\end{array}$ & $\begin{array}{l}\text { To evaluate the } \\
\text { effects of } \\
\text { COVID-19 } \\
\text { home } \\
\text { confinement on } \\
\text { the food habits, } \\
\text { lifestyle, and } \\
\text { emotional } \\
\text { balance }\end{array}$ & $\begin{array}{c}\uparrow \text { weight }(38.8 \%) \text {, average weight gain of } 2.57 \mathrm{~kg}, \downarrow \text { weight }(31.1 \%) \text {, } \\
\text { an average of } 2.81 \mathrm{~kg} \\
\text { EEQ score was positively correlated with weight gain (Rs }=0.19 ; \mathrm{p}< \\
0.05)\end{array}$ \\
\hline $\begin{array}{l}\text { Marchitelli et al., } 2020 \\
\text { Italy (43) }\end{array}$ & Cross-sectional & $\begin{array}{l}\text { Patients with } \\
\text { overweight or } \\
\text { obesity with or } \\
\text { without a } \\
\text { psychiatric } \\
\text { diagnosis } \\
(\geq 18 \text { years }) \\
(n=110)\end{array}$ & $\begin{array}{c}\text { To investigate } \\
\text { the impact of } \\
\text { psychological } \\
\text { and } \\
\text { psychosocial } \\
\text { variables on } \\
\text { weight gain in } \\
\text { patients affected } \\
\text { by } \\
\text { overweight/obes } \\
\text { ity with or } \\
\text { without a } \\
\text { psychiatric } \\
\text { diagnosis during } \\
\text { the COVID-19 } \\
\text { lockdown }\end{array}$ & $\begin{array}{l}\uparrow \text { weight: patients without a psychiatric diagnosis (about } 50 \% \text { ), and } \\
\text { with a psychiatric diagnosis }(66 \%) \\
\text { Weight gain predictors on patients with psychiatric diagnosis: binge } \\
\text { eating behaviors, which preceded the lockdown } \\
\text { Weight gain predictors on patients without a psychiatric diagnosis: } \\
\text { psychological stress }\end{array}$ \\
\hline
\end{tabular}




\begin{tabular}{|c|c|c|c|c|}
\hline $\begin{array}{l}\text { Martínez-de-Quel et al., } \\
2021 \\
\text { Spain (38) }\end{array}$ & $\begin{array}{l}\text { Longitudinal } \\
\text { observational }\end{array}$ & $\begin{array}{l}\text { Adults and } \\
\text { elderly } \\
\text { individuals. } \\
\text { The sample } \\
\text { was composed } \\
\text { mostly of } \\
\text { university } \\
\text { students } \\
(35.0 \pm 11.2 \\
\text { years }) \\
(\mathrm{n}=161)\end{array}$ & $\begin{array}{l}\text { To show the } \\
\text { impact that the } \\
\text { lockdown due to } \\
\text { COVID-19 had } \\
\text { on the physical } \\
\text { activity levels, } \\
\text { eating disorders, } \\
\text { and sleep quality }\end{array}$ & $\begin{array}{l}\text { Weight } \uparrow \text { significantly when compared before and during the lockdown } \\
\qquad(67.3 \pm 14.8 \text { vs. } 67.7 \pm 15.1, p=0.012) \\
\uparrow \text { number of people in the participants household during confinement } \\
\uparrow \text { weight gain }(\rho=0.217, p=0.006)\end{array}$ \\
\hline $\begin{array}{l}\text { Pellegrini et al., } 2020 \\
\text { Italy (44) }\end{array}$ & $\begin{array}{l}\text { Retrospective } \\
\text { observational }\end{array}$ & $\begin{array}{l}\text { Adults } \\
\text { individuals } \\
\text { undergoing } \\
\text { weight loss } \\
(47.9 \pm 16 \\
\text { years }) \\
(\mathrm{n}=150)\end{array}$ & $\begin{array}{c}\text { To evaluate } \\
\text { changes in } \\
\text { weight and } \\
\text { eating habits } \\
\text { among } \\
\text { individuals with } \\
\text { obesity treated } \\
\text { in a weight loss } \\
\text { program after } 1 \\
\text { month of } \\
\text { lockdown due to } \\
\text { the COVID-19 }\end{array}$ & $\begin{array}{c}\uparrow \text { significant from the average reported weight }(1.51 \mathrm{~kg}, \mathrm{p}<0.001) \text { and } \\
\text { BMI }\left(0.58 \mathrm{~kg} / \mathrm{m}^{2}, \mathrm{p}<0.001\right) \\
\text { Correlation between weight change with the consumption of sweets, } \\
\text { and self-reported anxiety/depression }\end{array}$ \\
\hline $\begin{array}{l}\text { Reyes-Olavarría et al., } \\
2020 \\
\text { Chile }(53)\end{array}$ & Cross-sectional & $\begin{array}{l}\text { Adults and } \\
\text { elderly } \\
\text { individuals } \\
(18-62 \text { years }) \\
(\mathrm{n}=700)\end{array}$ & $\begin{array}{l}\text { To determine } \\
\text { changes in } \\
\text { eating habits and } \\
\text { physical activity } \\
\text { caused by } \\
\text { confinement } \\
\text { during the }\end{array}$ & $\begin{array}{c}\text { Perception of } \uparrow \text { in body weight: men }(25.6 \%) \text { and women }(38.1 \%) \\
\text { (men vs. women, } \mathrm{p}=0.008) \\
\downarrow \text { weight: men }(19.8 \%) \text { and women }(14.2 \%) \\
\text { Maintenance: men }(54.6 \%) \text { and women }(47.7 \%) \\
\text { Association of variables with body weight increase: separated marital } \\
\text { status ( } \mathrm{p}=0.002) \text {; middle socioeconomic level }(\mathrm{p}=0.027) \text {; } \\
\text { consumption of fried foods } \geq 3 \text { times / week }(\mathrm{p}<0.001) \text {, low water }\end{array}$ \\
\hline
\end{tabular}




\begin{tabular}{|c|c|c|c|c|}
\hline & & & $\begin{array}{l}\text { COVID-19 } \\
\text { pandemic and } \\
\text { analyze their } \\
\text { associations } \\
\text { with changes in } \\
\text { body weight and } \\
\text { physical activity }\end{array}$ & $\begin{array}{l}\text { consumption }(\mathrm{p}=0.03) \text {, low consumption of legumes } \leq 1 \text { time / week } \\
(\mathrm{p}=0.03) \text {, consumption of junk food } \geq 3 \text { times } / \text { week }(\mathrm{p}=0.04) \\
\text { Weight gain: inversely association with fish consumption, physical } \\
\text { activity and positive association with sedentary time } \geq 6 \mathrm{~h} / \text { day }\end{array}$ \\
\hline $\begin{array}{c}\text { Sánchez-Sánchez et al., } \\
2020 \\
\text { Spain (40) }\end{array}$ & $\begin{array}{l}\text { Cross-sectional } \\
\text { descriptive }\end{array}$ & $\begin{array}{l}\text { Adolescents, } \\
\text { adults and } \\
\text { elderly } \\
\text { individuals } \\
(38.7 \pm 12.4 \\
\text { years }) \\
(\mathrm{n}=1.065)\end{array}$ & $\begin{array}{l}\text { To evaluate the } \\
\text { eating habits, } \\
\text { consumption, } \\
\text { and physical } \\
\text { activity before } \\
\text { and after a } \\
\text { COVID-19 } \\
\text { confinement } \\
\text { period }\end{array}$ & $\begin{array}{c}\uparrow \text { weight }(52.7 \%) \\
\text { Maintenance }(47.3 \%)\end{array}$ \\
\hline
\end{tabular}




\begin{tabular}{|c|c|c|c|c|}
\hline $\begin{array}{c}\text { Sidor and Rzymski, } 2020 \\
\text { Poland (23) }\end{array}$ & Cross-sectional & $\begin{array}{l}\text { Adults and } \\
\text { eutrophic } \\
\text { individuals } \\
(27.7 \pm 9.0 \\
\text { years }) \\
(\mathrm{n}=1.097)\end{array}$ & $\begin{array}{c}\text { To assess } \\
\text { whether eating } \\
\text { and drinking } \\
\text { habits were } \\
\text { affected during } \\
\text { the COVID-19 } \\
\text { quarantine }\end{array}$ & $\begin{array}{c}\uparrow \text { weight }(29.9 \%) \text { and } \downarrow \text { weight }(18.6 \%) \\
\text { The change in weight was correlated with BMI }(\mathrm{Rs}=0.21, \mathrm{p}<0.05) \\
\text { and age }(\mathrm{Rs}=0.15, \mathrm{p}<0.05)\end{array}$ \\
\hline $\begin{array}{l}\text { Zachary et al., } 2020 \\
\text { United States (52) }\end{array}$ & Cross-sectional & $\begin{array}{l}\text { Adults and } \\
\text { eutrophic } \\
\text { individuals } \\
(28.1 \pm 12.5 \\
\text { years }) \\
(\mathrm{n}=173)\end{array}$ & $\begin{array}{l}\text { To quantify the } \\
\text { impact that } \\
\text { COVID-19 } \\
\text { quarantine has } \\
\text { on behavior } \\
\text { associated with } \\
\text { weight gain }\end{array}$ & $\begin{array}{l}\text { Maintenance of weight (59\%), } \uparrow \text { of weight in } 5 \text { to } 10 \text { pounds }(22 \%) \text {, } \\
\text { and } \downarrow \text { of weight in more than } 10 \text { pounds }(4 \%) \\
\text { Individuals who increased the weight reported the highest increase in } \\
\text { relation to food, in relation to vision and smell, compared with those } \\
\text { who declared that they did not change everything }(\mathrm{p}=0.048)\end{array}$ \\
\hline
\end{tabular}




\section{Figures}

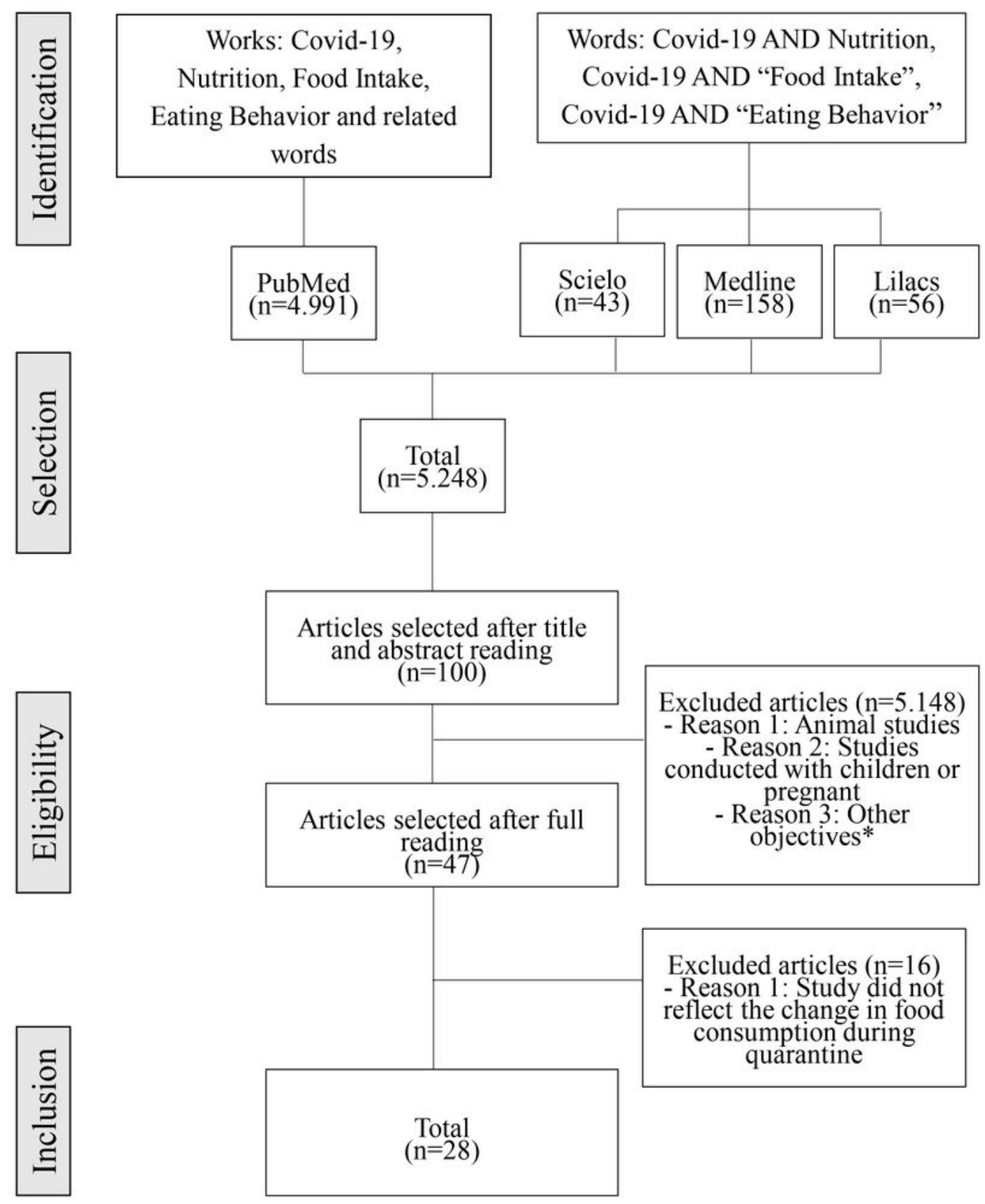

\section{Figure 1}

Flowchart based on the Preferred Reporting Items for Systematic Reviews and Meta-Analyses (PRISMA) (Moher et al. 2009). * Other objectives: studies that did not contribute to the answer to the question raised 
in this review, those referring to food insecurity in this quarantine period, others that dealt with specific nutrients and not changes in food consumption in a more general way as proposed by this review.

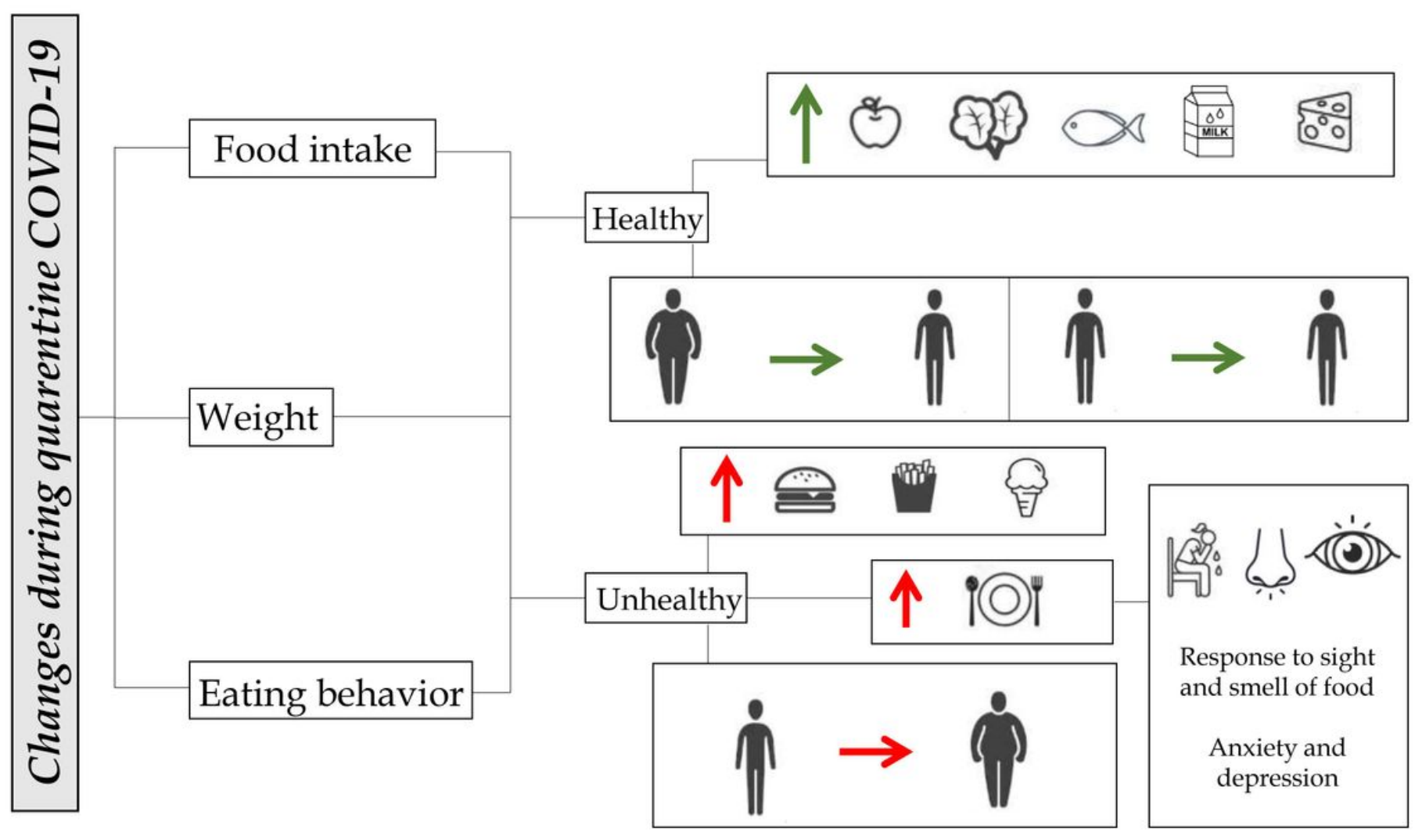

Figure 2

Changes in food intake, eating behavior, and body weight during COVID-19 quarantine 